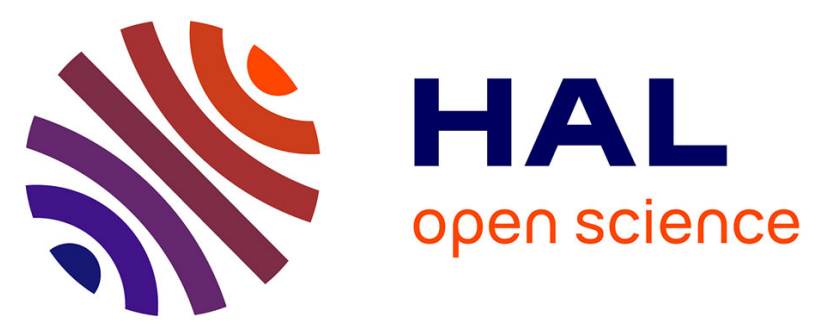

\title{
Active tectonics of the east Alborz mountains, NE Iran: Rupture of the left-lateral Astaneh fault system during the great 856 A.D. Qumis earthquake
}

James Hollingsworth, Amid Nazari, J.F. Ritz, Reza Salamati, Morteza

Talebian, Abbas Bahroudi, Richard Walker, Magali Rizza, James Jackson

\section{To cite this version:}

James Hollingsworth, Amid Nazari, J.F. Ritz, Reza Salamati, Morteza Talebian, et al.. Active tectonics of the east Alborz mountains, NE Iran: Rupture of the left-lateral Astaneh fault system during the great 856 A.D. Qumis earthquake. Journal of Geophysical Research, 2010, 115 (B12), pp.B12313.

10.1029/2009JB007185 . hal-00551330v2

\section{HAL Id: hal-00551330 \\ https://hal.science/hal-00551330v2}

Submitted on 30 Jan 2017

HAL is a multi-disciplinary open access archive for the deposit and dissemination of scientific research documents, whether they are published or not. The documents may come from teaching and research institutions in France or abroad, or from public or private research centers.
L'archive ouverte pluridisciplinaire HAL, est destinée au dépôt et à la diffusion de documents scientifiques de niveau recherche, publiés ou non, émanant des établissements d'enseignement et de recherche français ou étrangers, des laboratoires publics ou privés. 


\title{
Active tectonics of the east Alborz mountains, NE Iran: Rupture of the left-lateral Astaneh fault system during the great 856 A.D. Qumis earthquake
}

\author{
James Hollingsworth, ${ }^{1}$ Hamid Nazari, ${ }^{2}$ Jean-François Ritz, ${ }^{3}$ Reza Salamati, ${ }^{2,3}$ \\ Morteza Talebian, ${ }^{2}$ Abbas Bahroudi, ${ }^{4}$ Richard T. Walker, ${ }^{5}$ Magali Rizza, ${ }^{3}$ \\ and James Jackson ${ }^{6}$ \\ Received 3 December 2009; revised 6 August 2010; accepted 24 August 2010; published 9 December 2010.
}

[1] The 856 A.D. Qumis earthquake (M7.9) is the most destructive earthquake to have occurred in Iran, killing more than 200,000 people and destroying the cities of Damghan and the old Parthian capital of Shahr-i Qumis (Hecatompylos). This study combines evidence of historical seismicity with observations of the geomorphology and paleoseismology to provide the first detailed description of active faulting in the Damghan region of the east Alborz mountains, Iran. Regional left-lateral shear is accommodated on the Astaneh, Damghan, and North Damghan faults. Quaternary alluvial fans have been displaced along the Astaneh fault, with 15-20 m stream offsets recording the cumulative displacement over the last two to five earthquakes. A paleoseismology study from a single trench along a 5-10 km segment of the Astaneh fault reveals a rupture prior to 1300 A.D. and significantly later than 600 B.C. Despite the limitations of a single trench in documenting the spatial and temporal evolution of the fault over the late Quaternary, we are nevertheless able to bracket the last event to a time period consistent with the 856 A.D. earthquake. Two older earthquakes were also identified during the Holocene occurring between 600 B.C. and 4600 B.C. and between 4600 B.C. and 9600 B.C. The location of our trench within a bend on the Astaneh fault, which could act as a barrier to rupture propagation, means the three earthquakes recovered from our trench over the Holocene may represent a minimum. Further trenching will reveal how the Astaneh fault ruptures over repeated earthquakes and, consequently, the magnitude and extent of slip during the 856 A.D. earthquake.

Citation: Hollingsworth, J., H. Nazari, J.-F. Ritz, R. Salamati, M. Talebian, A. Bahroudi, R. T. Walker, M. Rizza, and J. Jackson (2010), Active tectonics of the east Alborz mountains, NE Iran: Rupture of the left-lateral Astaneh fault system during the great 856 A.D. Qumis earthquake, J. Geophys. Res., 115, B12313, doi:10.1029/2009JB007185.

\section{Introduction}

[2] Iran forms a relatively compact zone of active continental deformation resulting from the northward collision of Arabia with Eurasia during late Cenozoic times, and which continues to the present-day at a rate of $25 \mathrm{~mm} / \mathrm{yr}$ (Figure 1a) [Masson et al., 2007]. Unlike older, more complicated collisional settings, Iran provides an opportunity to look at

\footnotetext{
${ }^{1}$ Division of GPS, California Institute of Technology, Pasadena, California, USA.

${ }^{2}$ Research Institute for Earth Sciences, Geological Survey of Iran, Tehran, Iran.

${ }^{3}$ Géosciences Montpellier, UMR 5243, Université Montpellier 2, Montpellier, France.

${ }^{4}$ Exploration Department, University of Tehran, Tehran, Iran.

${ }^{5}$ COMET-NCEO and Department of Earth Sciences, University of Oxford, Oxford, UK.

${ }^{6}$ COMET-NCEO and Department of Earth Sciences, University of Cambridge, Cambridge, UK.

Copyright 2010 by the American Geophysical Union. 0148-0227/10/2009JB007185
}

processes of continental deformation while they operate. The arid climate, low rates of erosion, and minimal vegetation cover across the majority of the country result in excellent preservation and exposure of surface deformation produced by active faults. Iran is also one of the most seismically active continental regions in the world (Figure 1b) and owing to the long history of civilization in the region, the extensive historical record of large earthquakes stretches back $\sim 2,000$ years [Ambraseys and Melville, 1982]. Because earthquake repeat times are often thousands of years, instrumental earthquake records do not give a complete picture of active deformation [e.g., Bilham, 2004; Nazari et al., 2009a, 2009b]. In these circumstances, the historical record of seismicity is an extremely important resource to studies of both continental tectonics and seismic hazard assessment in deforming regions such as Iran. However, it is often difficult to identify with confidence the fault responsible for a particular historical earthquake. In this paper we investigate the $856 \mathrm{~A}$. D. Qumis (or Qoomes) earthquake in NE Iran, which is one of the five most destructive known earthquakes recorded 

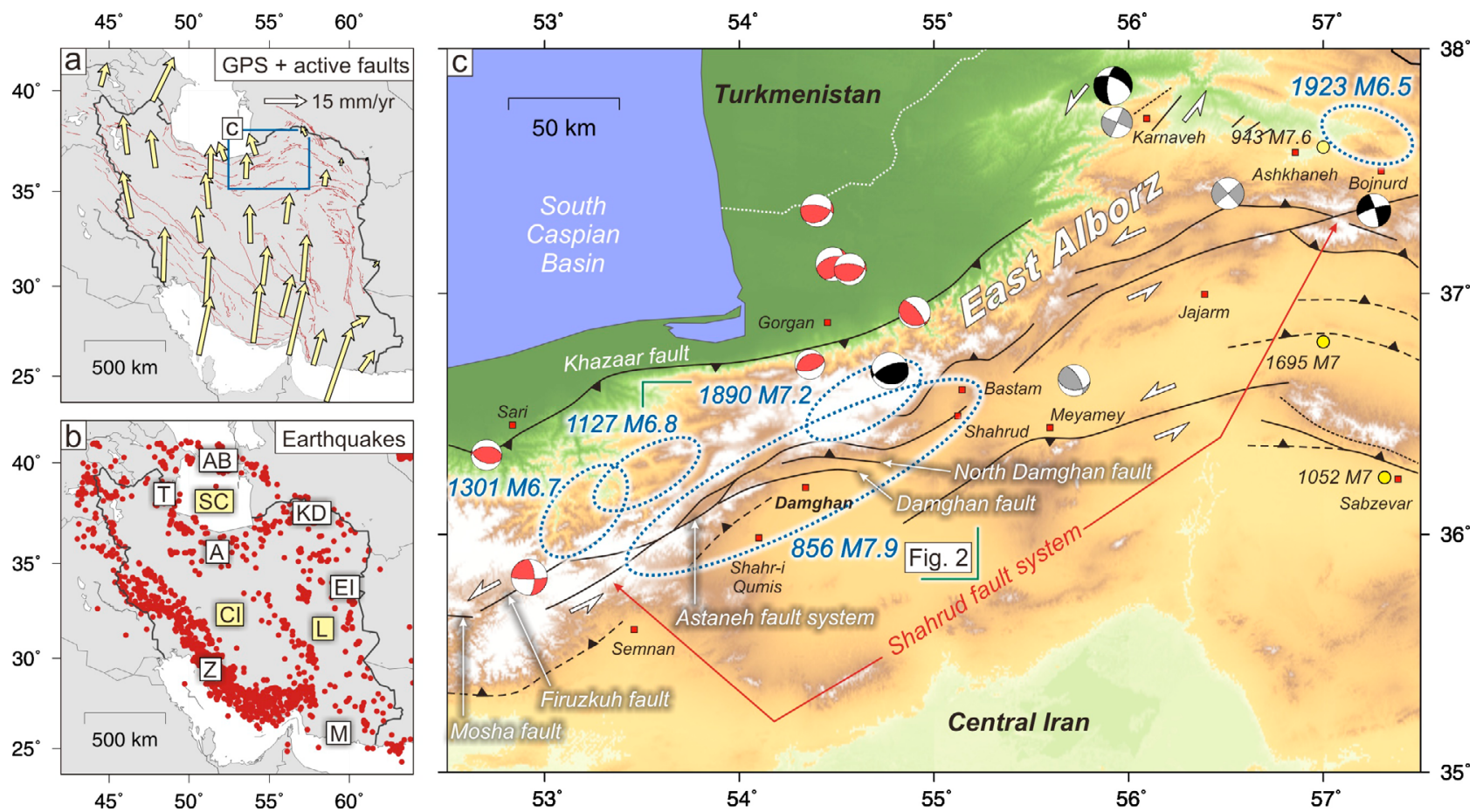

Figure 1. (a) GPS velocities relative to Eurasia record $\sim 25 \mathrm{~mm} / \mathrm{yr} \mathrm{N}-\mathrm{S}$ shortening between Arabia and Eurasia, which is accommodated throughout Iran [Masson et al., 2007]. Red lines show locations of active faults [Hollingsworth et al., 2008]. (b) Locations of earthquake epicenters $\left(M_{w} \geq 5.1\right)$ across Iran during the period 1964-1998 [Engdahl et al., 1998, 2006]. Earthquakes are concentrated in the Zagros (Z), Talysh (T), Alborz (A), and Kopeh Dagh (KD) mountain belts; the strike-slip fault systems of east Iran (EI); and the Apsheron-Balkan (AB) and Makran (M) subduction zones, which surround the relatively aseismic central Iran (CI), Lut desert (L), and South Caspian (SC) blocks. (c) Seismotectonic map of the east Alborz mountains, west of $57^{\circ} \mathrm{E}$. Thrust faulting occurs north of the range on the Khazaar fault, and left-lateral strike-slip occurs on the south side of the range on the Shahrud fault system (shown by black lines). Fault plane solutions for recent large earthquakes $\left(M_{w}>5\right)$ are shown in red (from the Harvard catalogue), grey [Jackson and Fitch, 1979; Jackson and McKenzie, 1984], and black [Baker, 1993; Priestley et al., 1994] (see Table 1). Dotted blue ellipses show the approximate region of maximum destruction for large historical earthquakes which have affected the Damghan and Shahrud regions [Ambraseys and Melville, 1982]. Where insufficient data exist, anapproximate location is given by a yellow dot.

globally (http://earthquake.usgs.gov/regional/world/most destructive.php). We combine both remote and field-based observations of the geomorphology with historical accounts of earthquake damage to identify active faults in the Qumis region of NE Iran (southern east Alborz mountains). New paleoseismology results from a trench opened across a section of the Astaneh fault, north of Damghan city, reveal the Holocene slip history of this fault, which is then used to assess the seismic hazard posed by this fault to the surrounding region. The goals of this study are therefore to improve our understanding of how regional shear is accommodated on individual fault systems in the east Alborz mountains, better quantify the slip history for these faults, identify the source of the 856 A.D. Qumis earthquake, and to improve our general understanding of the seismic hazard posed to cities in this region. Although remote sensing and paleoseismology are now well established techniques for identifying active faults and quantifying fault slip history within a region [Sieh et al., 1989; Pantosti et al., 1993; Rockwell et al., 2000; Lin et al., 2006; Hartleb et al., 2006], such combined studies are only beginning to emerge from Iran [Nazari et al., 2009a, 2009b]. The Astaneh fault forms part of a major zone of left-lateral shear which strikes for $>800 \mathrm{~km}$ across northern Iran. This study is therefore of much more than local significance, as it forms an important example of how a major intracontinental strike-slip fault system has evolved over the late Quaternary [see also Prentice et al., 2002; Washburn et al., 2003; Daeron et al., 2004; Dolan et al., 2007; Nissen et al., 2009; Cowgill et al., 2009]. Furthermore, in contrast to well-studied plate boundary structures such as the North Anatolian fault [Klinger et al., 2003; Hartleb et al., 2006; Kondo et al., 2010], San Andreas fault [Sieh, 1981; Schwartz and Coppersmith, 1984], and Alpine fault [Sutherland and Norris, 1995; Wells et al., 1999], the northern Iran left-lateral shear zone slips at a much slower rate, and lies within a relatively complicated structural setting.

\section{Tectonic Setting and Seismicity}

[3] In north Iran, the Alborz mountains form a sinuous range over $1,200 \mathrm{~km}$ long, separating the high plateau of central Iran $(\sim 1,000 \mathrm{~m}$ elevation) from the South Caspian basin, which lies near sea level (Figure 1c). The active tectonics of the west and central Alborz are relatively well 
Table 1. Significant Earthquakes Occurring in the East Alborz Mountains, NE Iran, Over the Last $\sim 2000$ Years $^{\mathrm{a}}$

\begin{tabular}{|c|c|c|c|c|c|c|c|c|c|c|}
\hline Date & $\begin{array}{l}\text { Local } \\
\text { Time }\end{array}$ & $\begin{array}{l}\text { Latitude } \\
\left({ }^{\circ} \mathrm{N}\right)\end{array}$ & $\begin{array}{c}\text { Longitude } \\
\left({ }^{\circ} \mathrm{E}\right)\end{array}$ & $\begin{array}{l}\text { Approximate } \\
\text { Location }\end{array}$ & Magnitude & & & & & Reference \\
\hline 856.12 .22 & - & 36.2 & 54.3 & Damghan & 7.9 & - & - & - & - & 1 \\
\hline 943.08 & - & 37.6 & 57.0 & Bojnurd & 7.6 & - & - & - & - & 1 \\
\hline 1127 & - & 36.3 & 53.6 & Sari & 6.8 & - & - & - & - & 1 \\
\hline 1301 & - & 36.1 & 53.2 & Sari & 6.7 & - & - & - & - & 1 \\
\hline 1890.07 .11 & $00: 55$ & 36.56 & 54.62 & Shahrud & 7.2 & - & - & - & - & 1 \\
\hline 1923.09 .17 & 07:09:17 & 37.63 & 57.21 & Bojnurd & 6.5 & - & - & - & - & 1 \\
\hline Date & $\begin{array}{l}\text { Time } \\
\text { (GMT) }\end{array}$ & $\begin{array}{l}\text { Latitude } \\
\left({ }^{\circ} \mathrm{N}\right)\end{array}$ & $\begin{array}{l}\text { Longitude } \\
\left({ }^{\circ} \mathrm{E}\right)\end{array}$ & $\begin{array}{l}\text { Approximate } \\
\text { Location }\end{array}$ & $\begin{array}{c}M_{w} \\
\left(\mathrm{~N} \mathrm{~m}^{-1}\right)\end{array}$ & $\begin{array}{c}\text { Depth } \\
(\mathrm{km})\end{array}$ & $\begin{array}{l}\text { Strike } \\
(\text { deg) }\end{array}$ & $\begin{array}{l}\text { Dip } \\
(\operatorname{deg})\end{array}$ & $\begin{array}{l}\text { Rake } \\
(\text { deg })\end{array}$ & Reference \\
\hline 1970.07 .30 & $00: 52: 20$ & 37.84 & 55.89 & Karnaveh & 6.4 & 11 & 293 & 56 & -150 & 2,3 \\
\hline 1971.02 .14 & 02:14:16 & 36.55 & 55.69 & Meyamey & 5.7 & 11 & 95 & 40 & 43 & $2,4,5$ \\
\hline 1973.08 .02 & $19: 56: 25$ & 37.35 & 56.48 & Shoqan & 5.1 & 7 & 48 & 89 & 0 & 2,5 \\
\hline 1974.03.07 & 11:36:02 & 37.61 & 55.90 & Karnaveh & 5.2 & 7 & 23 & 89 & 0 & 2,5 \\
\hline 1985.10 .29 & 03:13:42 & 36.68 & 54.77 & Gorgan & 6.2 & 13 & 246 & 66 & 71 & 2,4 \\
\hline 1990.01 .20 & 01:27:11 & 35.90 & 52.98 & Semnan & 5.9 & 25 & 357 & 66 & 172 & 2,6 \\
\hline 1992.02 .22 & 14:05:56 & 36.30 & 52.73 & Sari & 5.1 & 5 & 292 & 45 & 30 & 2,6 \\
\hline 1998.08 .04 & $11: 41: 57$ & 37.22 & 57.33 & Bojnurd & 5.7 & 8 & 252 & 79 & -8 & 2,7 \\
\hline 2000.08 .16 & 12:53:01 & 36.73 & 54.38 & Gorgan & 4.9 & 15 & 240 & 34 & 78 & 2,6 \\
\hline
\end{tabular}

${ }^{\mathrm{a}}$ Historical earthquakes are from 1, Ambraseys and Melville [1982]; instrumental earthquakes are from 2, Engdahl et al. [2006]; 3, Jackson and Fitch [1979]; 4, Priestley et al. [1994]; 5, Jackson and McKenzie [1984]; 6, Harvard CMT (http://www.globalcmt.org/); 7, Hollingsworth [2007]. The determination of Magnitude for historical earthquakes is based on written accounts of destruction, and consequently they represent poorly constrained estimates. Nevertheless, they are useful in identifying when significant earthquakes occurred between 800 and 1962 A.D.

understood, and appear to accommodate N-S regional shortening by partitioning onto separate thrust and left-lateral strike-slip faults [e.g., Jackson et al., 2002; Allen et al., 2003; Vernant et al., 2004b; Ritz et al., 2006; Guest et al., 2006; Tatar et al., 2007]. A similar tectonic framework has been established for the east Alborz (between 53 and $57^{\circ} \mathrm{E}$ ), based primarily on observations of the tectonic geomorphology; $\mathrm{N}-\mathrm{S}$ shortening is partitioned onto the Khazaar thrust [Tatar et al., 2007], which runs along the north side of the range, and the left-lateral Shahrud fault system, which runs along the south side of the range [Wellman, 1966; Hollingsworth et al., 2008] (see Figure 1c). Nevertheless, our understanding of how the east Alborz mountains accommodate regional shortening, and particularly left-lateral shear, at the scale of individual faults remains poor.

[4] One reason for this lies in the relatively low number of large earthquakes that have occurred between 53 and $57^{\circ} \mathrm{E}$ over the last 50 years (Figure 1c and Table 1 list all large historical and recent earthquakes to have affected the east Alborz range between 53 and $57^{\circ} \mathrm{E}$ ). Fault plane solutions of moderate-sized $\left(M_{w} 4.9-6.2\right)$ earthquakes near Sari and Gorgan, along the north side of the range, indicate acrossstrike shortening on the Khazaar thrust fault, which thrusts central Iran over the South Caspian lowlands (Figure 1c). The only destructive left-lateral earthquake between 53 and $57^{\circ} \mathrm{E}$ occurred on 1970.07.30 near Karnaveh (Figure 1c). A small number of moderate-sized strike-slip earthquakes have occurred in the region (near Bojnurd, Meyamey, and Semnan), in which the left-lateral nodal planes are consistent with the strike of active left-lateral faults identified in the geomorphology.

[5] Despite the relative seismic quiescence over the last 50 years, the east Alborz has experienced a number of large destructive earthquakes throughout historical times, a feature typical of the whole NE Iran region (see Table 1) [see Ambraseys and Melville, 1982; Masson et al., 2005]. Four of these events occurred between 53 and $55^{\circ} \mathrm{E}$, and include the 856 A.D. Qumis earthquake. Two large earthquakes occurred in the area north and west of Bojnurd, which has also experienced recent large earthquakes, and forms a structurally complicated zone where left-lateral faults of the east Alborz intersect with right-lateral faults of the central Kopeh Dagh [Hollingsworth et al., 2008, 2010].

[6] The ancient city of Damghan (current population $60,000)$ lies on the southern margin of the Alborz mountains near $54.5^{\circ} \mathrm{E}$ (Figures 1c and 2). During the Middle Ages (652-1501 A.D.), Damghan was an important city in Iran, and was the capital city of the Qumis region whose importance was greatly diminished after the devastating Qumis earthquake in 856 A.D. This earthquake severely affected a $150 \mathrm{~km}$ long region surrounding Damghan (dotted blue ellipse in Figure 1), killing over 200,000 people $(\sim 45,000$ were killed in the city itself), and destroying practically all the villages in the region [Ambraseys and Melville, 1982]. The high number of fatalities make this earthquake the most devastating to have affected Iran in recorded history, and the 5th most destructive globally. Written accounts describe extensive ground deformations in the mountains north of the city, which included coseismic surface ruptures, and almost certainly included landsliding caused by strong ground motions. The old Parthian capital city of Shahr-i Qumis (Hecatompylos), which lies $\sim 30 \mathrm{~km}$ SW of Damghan, was also destroyed, and probably abandoned after the earthquake. Damage extended $70 \mathrm{~km}$ NE of Damghan, where one third of Bastam collapsed [Ambraseys and Melville, 1982].

[7] The region of maximum destruction resulting from the earthquake coincides with three faults which show signs of activity during the late Quaternary period: the Astaneh, North Damghan, and Damghan faults (Figure 2), which collectively make up the SW section of the left-lateral Shahrud fault system (Figure 1c). Although all three faults show signs of recent activity, the Astaneh fault is the longest fault in the 


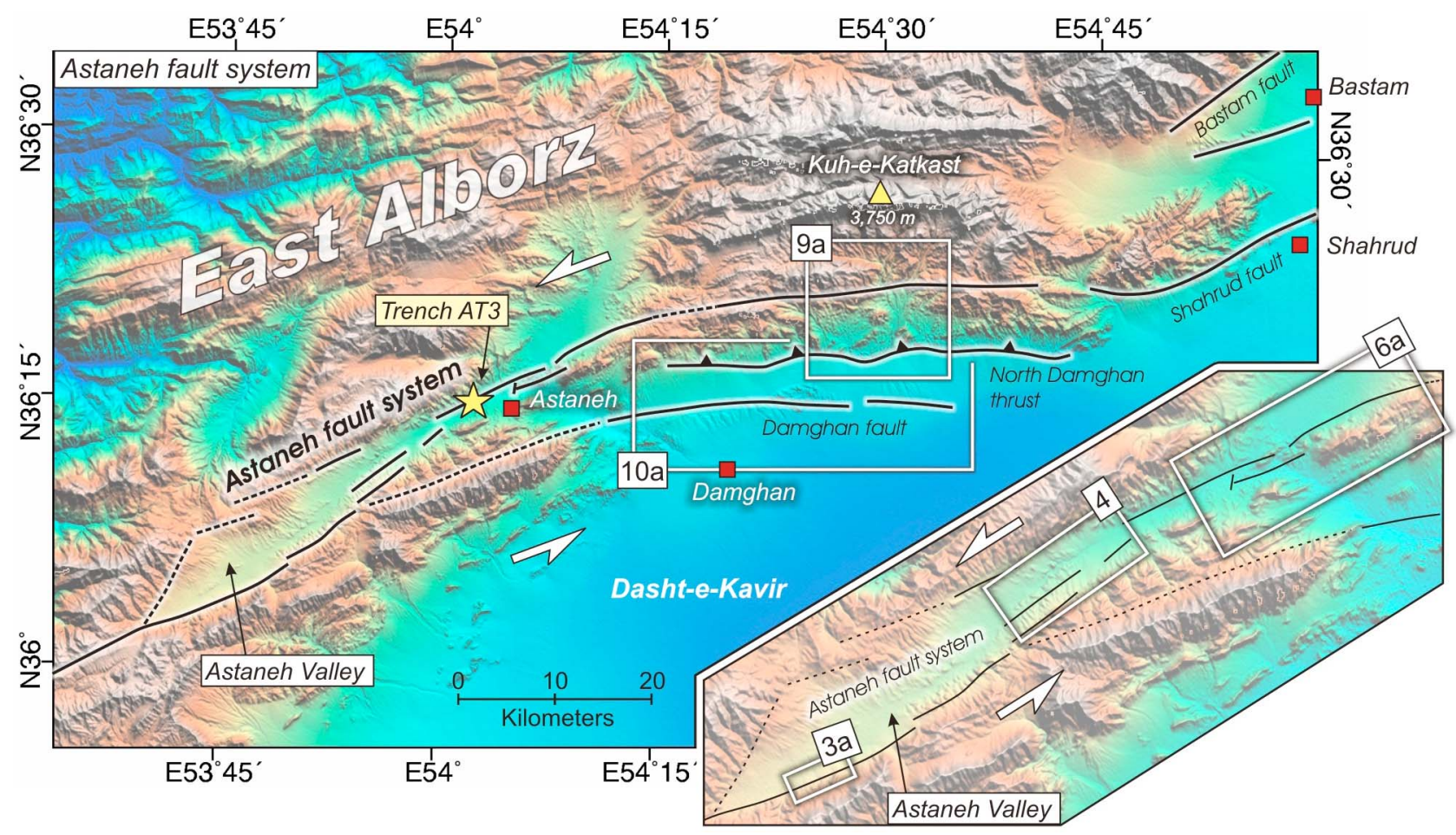

Figure 2. Topographic map of the Damghan region of the east Alborz, which was severely damaged during the 856 A.D. earthquake. The location corresponds to the blue damage ellipse for the 856 A.D. earthquake shown in Figure 1. The Shahrud fault system (shown by black lines) forms a complicated zone of left-lateral shear along the range front. Various step overs and bends in fault segments which make up the zone have produced regions of uplift (Kuh-e-Katkast restraining bend) and subsidence (Astaneh valley). The Astaneh valley is a major left-lateral pull-apart basin, which lies west of Damghan. White boxes show the locations of Figures 9a and 10a, which show details from the geomorphology along the fault system. Inset shows a zoom of the Astaneh Valley, for clarity, with locations of Figures 3a, 4, and 6a. Yellow star shows the location of trench AT3 discussed in section 5. For a more regionally extensive map of active faults, see Hollingsworth et al. [2008].

region, extending more than $150 \mathrm{~km}$ through the mountains, and coincides exactly with the zone of maximum destruction. It is therefore the most likely candidate for the fault which ruptured during the 856 A.D. earthquake. The Astaneh fault is clearly expressed in the Quaternary geomorphology along its entire length, highlighting its potential for generating large earthquakes. In section 4 we discuss the tectonic geomorphology of the Astaneh fault, North Damghan and Damghan faults, of which relatively little is known [Berberian et al., 1996], and highlight their potential for generating large magnitude earthquakes. In section 5 we discuss the paleoseismology results from a trench excavated along a section of the Astaneh fault system $15 \mathrm{~km}$ west of Astaneh village, which indicates the Astaneh fault ruptured during the 856 A.D. Qumis earthquake.

\section{Active Tectonics of the Damghan Region}

[8] The Astaneh fault forms a system of overlapping, and in places discontinuous fault segments typically $10-20 \mathrm{~km}$ long [Klinger, 2010], which strike NE-SW through the southern part of the Alborz range (Figure 2) [see also Berberian et al., 1996]. The fault bends SW of Astaneh village producing a large left-lateral pull-apart basin known as the Astaneh Valley (1600-1800 m elevation, see also
Figure 2). The fault continues SW of the Astaneh valley as far as $53^{\circ} \mathrm{E}$, at which point regional shear appears to be transferred to the subparallel Firuzkuh fault, which lies $20 \mathrm{~km}$ to the north (based on lineations visible in $90 \mathrm{~m}$ SRTM digital topography, Figure 1c). To the NE of Astaneh village $\left(54.10^{\circ} \mathrm{E}\right)$, the fault bends back into the mountains forming a local zone of compression in the Kuh-e-Katkast restraining bend (3,750 m elevation) NNE of Damghan city. The fault then exits the Alborz and continues NE along the southern edge of the range toward the city of Shahrud, where it is known as the Shahrud fault. The Damghan fault lies south of the Astaneh fault, from which it splays, and cuts across the piedmont directly north of Damghan city. Ambraseys and Melville [1982] attributed the 865 A.D. earthquake to slip on this fault, based on its proximity to Damghan and its clear expression in the Quaternary geomorphology. The North Damghan thrust runs parallel to the Astaneh fault along the edge of the topography which forms the Kuh-e-Katkast high, north of the Damghan fault. Each of these faults are discussed in turn below.

\subsection{Astaneh Fault}

[9] Because the Astaneh fault system has experienced no large earthquakes over the last 50 years, the sense of slip on the fault cannot be determined using teleseismic methods 
Table 2. Locations in the Astaneh Valley Where the Late Quaternary Geomorphology Has Been Clearly Displaced by the Astaneh Fault and a Measurement Made of the Offset ${ }^{\mathrm{a}}$

\begin{tabular}{lccccc}
\hline Site & $\begin{array}{c}\text { Latitude } \\
\left({ }^{\circ} \mathrm{N}\right)\end{array}$ & $\begin{array}{c}\text { Longitude } \\
\left({ }^{\circ} \mathrm{E}\right)\end{array}$ & $\begin{array}{c}\text { Displacement } \\
(\mathrm{m})\end{array}$ & $\begin{array}{c}\text { Age } \\
(\mathrm{ky})\end{array}$ & Figure \\
\hline 1 & 36.06669 & 53.74991 & $18 \pm 3$ & $<13$ & $3 \mathrm{~b}$ \\
$\mathrm{2a}$ & 36.17135 & 53.89648 & $60 \pm 7$ & - & $5 \mathrm{a}$ \\
$\mathrm{2b}$ & 36.17016 & 53.89374 & $120 \pm 20$ & $\sim 50$ & $5 \mathrm{a}$ \\
3a & 36.17532 & 53.90225 & $480 \pm 30$ & - & $5 \mathrm{~b}$ \\
3b & 36.18119 & 53.91421 & $425 \pm 25$ & - & $5 \mathrm{~b}$ \\
4 & 36.19494 & 53.94175 & $30 \pm 5$ & - & $5 \mathrm{c}$ \\
5 & 36.18628 & 53.95010 & $500 \pm 30$ & - & $5 \mathrm{~d}$ \\
6a & 36.20723 & 53.94896 & $20 \pm 5$ & $<13$ & $5 \mathrm{e}$ \\
6b & 36.20840 & 53.95182 & $14 \pm 5$ & $<13$ & $5 \mathrm{e}$ \\
6c & 36.06669 & 53.74991 & $18 \pm 3$ & $<13$ & $5 \mathrm{e}$ \\
$7 \mathrm{a}$ & 36.22548 & 53.99485 & $17 \pm 3$ & $<13$ & $5 \mathrm{f}$ \\
$7 \mathrm{~b}$ & 36.22527 & 53.99446 & $13 \pm 3$ & $<13$ & $5 \mathrm{f}$ \\
$7 \mathrm{c}$ & 36.22420 & 53.99257 & $18 \pm 4$ & $<13$ & $5 \mathrm{f}$ \\
$7 \mathrm{~d}$ & 36.22399 & 53.99215 & $15 \pm 3$ & $<13$ & $5 \mathrm{f}$ \\
8 & 36.32121 & 54.18287 & $20 \pm 5$ & $<13$ & $6 \mathrm{c}$ \\
$9 \mathrm{a}$ & 36.29921 & 54.13670 & $18 \pm 3$ & $<13$ & $7 \mathrm{~b}$ \\
$9 \mathrm{~b}$ & 36.29693 & 54.13222 & $575 \pm 35$ & - & $7 \mathrm{a}$ \\
$10 \mathrm{a}$ & 36.25768 & 54.04453 & $50 \pm 10$ & $\sim 30$ & $8 \mathrm{~b}$ \\
$10 \mathrm{~b}$ & 36.25619 & 54.04199 & $47 \pm 4$ & $\sim 30$ & $8 \mathrm{~d}$ \\
\hline
\end{tabular}

${ }^{\text {a }}$ Site numbers correspond to those discussed in the text and figures. The magnitudes of displacement are given, with the errors estimated from visual inspection of satellite and topographic data (corresponding figures for each offset are shown). An age estimate for the displaced geomorphic feature at each location is given; the youngest incised alluvial fan deposits which are typically displaced by $15-20 \mathrm{~m}$ are assumed to be less than $13 \mathrm{ky}$, based on the timing of a regional Holocene incision event documented at several sites throughout Iran [e.g., Fattahi et al., 2006]. Preliminary age estimates at sites $2 \mathrm{~b}, 10 \mathrm{a}$, and $10 \mathrm{~b}$ are from optically stimulated luminescence dating of alluvial material (M. Rizza, personal communication, 2010).

[e.g., Jackson, 2001, and references therein]. Nevertheless, the large-scale morphology and pattern of restraining and releasing bends along the Astaneh fault system are consistent with a left-lateral sense of motion. Furthermore, the complex pattern of faults bounding the margins of the Astaneh valley all show a dominant left-lateral component, coupled with a small basinward normal component: typical of pull-apart basins. Quaternary sedimentation in the Astaneh valley has resulted in numerous geomorphological markers which preserve the sense of motion where they are cut by segments of the Astaneh fault. Various offsets identified and measured on the Astaneh fault are given in Table 2, and are discussed in detail below.

\subsubsection{Astaneh Valley}

[10] The Astaneh valley is a narrow NE-SW trending basin, through which the Astaneh river drains to the NE as far as Astaneh village, before draining SE toward Damghan and the Dasht-e-Kavir desert (Figure 2). Left-lateral motion on fault segments bounding the north side of the valley have resulted in rivers being deflected downslope as they drain into the valley. Consequently, left-lateral offsets are poorly preserved on the northern side of the valley. The opposite is true for the southern side, where left-lateral motion causes drainage to be deflected upslope, and consequently leftlateral offsets are often well preserved. Figure 3a shows a fault segment from the SW corner of the Astaneh Valley, which cuts across a system of Quaternary alluvial fans. The rapid change in polarity of uplift from "down to the south" in the west, to "down to the north" in the east, over a distance of only $\sim 1 \mathrm{~km}$, indicates a near-vertical dip of the fault, and is consistent with strike-slip motion. Therefore, small fluctuations in the dip will be enough to cause the sense of uplift to change locally along the fault. Figures $3 b-3 e$ show in detail where the fault segment cuts across the recent alluvial fan deposits in the western end of the Astaneh valley (site 1 in Table 2). A series of streams draining over the fans have been offset across the fault in a left-lateral sense by $18 \pm 3 \mathrm{~m}$. Abandonment of the youngest alluvial fans determined at several sites throughout $\mathrm{E}$ and NE Iran date from $11 \pm 2 \mathrm{ky}$ [Regard et al., 2005; Fattahi et al., 2006, 2007]. Therefore, it is likely these $15-21 \mathrm{~m}$ stream offsets represent the cumulative Holocene offset.

[11] The clearest examples of displaced geomorphology on the Astaneh fault occur in the eastern end of the valley. Fault segments running along the southern side of the valley form several splays, which step northward into the valley and disrupt a system of alluvial fans (Figure 4). Rivers draining across the various fault segments have been deflected to the west (upslope), and a small left-lateral pull-apart basin has opened up where the fault segments step to the north. Figure 4 shows the location of the various images in Figure 5, which show late Quaternary left-lateral offsets along these fault segments.

[12] Figure 5a shows a detail from one of the Astaneh fault segments which cuts through the Astaneh Valley. The fault cuts linearly across a series of alluvial fan deposits. A northward draining river has been deflected upslope to the west (orange line), before being captured by a river downslope to the east (blue line). Alluvial material deposited by the dry river before it switched to its present-day eastern course has now been displaced by $\sim 60 \mathrm{~m}$ across the fault (Figure $5 \mathrm{a}$ inset, and site $2 \mathrm{a}$ in Table 2). Also, the western terrace riser has been offset by a minimum of $120 \pm 20 \mathrm{~m}$ (site $2 \mathrm{~b}$ ). The vertical offset across the fault appears negligible, suggesting the Astaneh fault is predominantly strike-slip.

[13] Figure 5b shows a 3-D perspective view (looking south) of the same segment of the Astaneh fault system (see Figure 4 for location). Blue lines indicate deflections of rivers by $400-500 \mathrm{~m}$ to the west (upslope), produced by left-lateral motion (sites $3 \mathrm{a}$ and $3 \mathrm{~b}$ ). It should be noted that these rivers would not be deflected upslope with a right-lateral sense of slip. The orange line indicates a beheaded and now dry river valley, which also trails in a left-lateral sense.

[14] A detail of the small left-lateral pull-apart basin shown from Figure 4 is shown in Figure $5 \mathrm{c}$. Here, the old river course (orange line) has been deflected to the west (upslope) before being captured by a river to the east (downslope). Due to the increased gradient of the new postcapture river course, the river has incised leaving an abandoned Quaternary terrace which records the older westward course. The western edge of this surface is highlighted by a dotted yellow line, which has been displaced by $30 \pm 5 \mathrm{~m}$ across the fault on the southern side of the basin (site 4). A smaller vertical component of motion is also present, highlighted by shadows running $\mathrm{E}-\mathrm{W}$ along the fault scarp (between the black arrows). These are less clear on the northern side of the basin, which faces the sun.

[15] Immediately south of the pull-apart basin in Figure 5c, left-lateral motion on a different segment of the Astaneh fault, which runs along the southern edge of the valley, has caused the large-scale $500 \pm 30 \mathrm{~m}$ deflection of rivers draining northward into the basin (Figure 5d, site 5). The region shown 

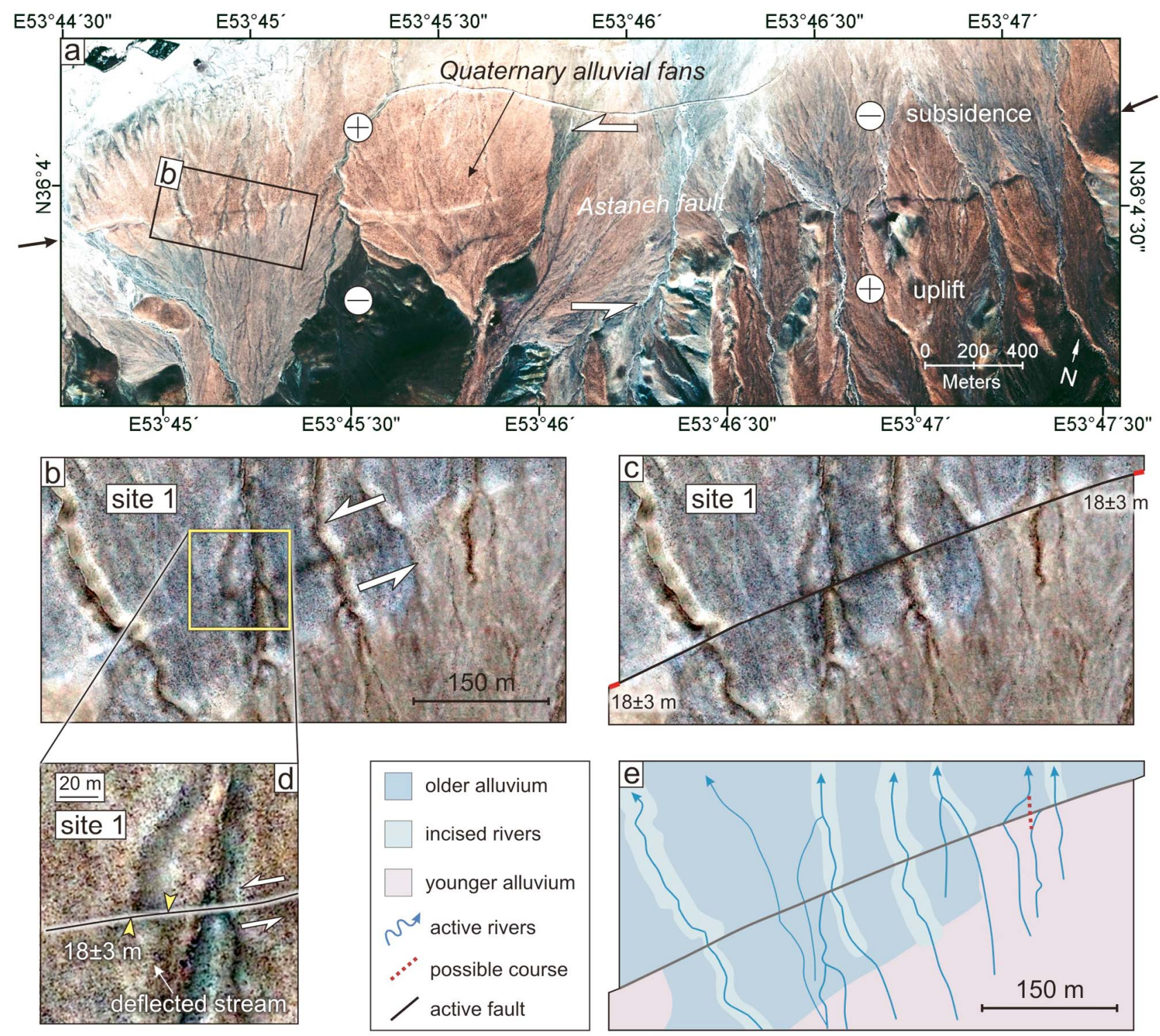

Figure 3. (a) Quickbird satellite image of the Astaneh fault on the south side of the valley (see Figure 2 for location). The fault runs between the two black arrows, and cuts across a series of late Quaternary alluvial fans. The polarity of uplift switches over a short distance along strike, suggesting a steep fault dip. (b) Quickbird image showing the fault cutting across an alluvial fan surface, displacing a series of streams which drain across the fault. (c) Reconstruction of the drainage in Figure 3b indicates $18 \pm 3 \mathrm{~m}$ left-lateral offset. (d) Close-up image of the fault which has offset a stream by $18 \pm 3 \mathrm{~m}$ (site 1 in Table 2; see yellow box in Figure $3 b$ for location). (e) Simplified map of the geomorphology, showing the drainage reconstruction in Figure $3 \mathrm{c}$ for clarity.

in Figure 5e lies just north of the pull-apart in Figure 5c (see also Figure 4). Two fault segments run parallel to each other between the black arrows, producing a small push-up structure. Along the northern fault segment several streams show deflections of $14-20 \mathrm{~m}$ (sites $6 \mathrm{a}, 6 \mathrm{~b}$, and $6 \mathrm{c}$ ). Figure $5 \mathrm{f}$ shows two parallel fault segments a few kilometers east of Figure 5e. The edge of the terrace riser in the top right of the image (shown by dotted yellow lines) has been displaced in a leftlateral sense across the southern fault segment by $17 \pm 3 \mathrm{~m}$ (site 7a). Also, southwest of site 7a streams show 13-18 m left-lateral deflections (sites 7b, 7c, and 7d).
[16] The left-lateral offsets determined above using $0.6 \mathrm{~m}$ resolution Quickbird satellite imagery are all in agreement with estimates made from the topography (digital elevation models for each site were made using kinematic GPS survey data and are available, along with the raw survey data, in the auxiliary material). ${ }^{1}$ Furthermore, it should be noted that a small normal component exists on many of the examples shown in Figure 5 (typically a ratio of between 1:10-20). The

\footnotetext{
${ }^{1}$ Auxiliary material data sets are available at $\mathrm{ftp}: / / \mathrm{ftp}$. agu.org/apend/jb/ 2009JB007185.
} 


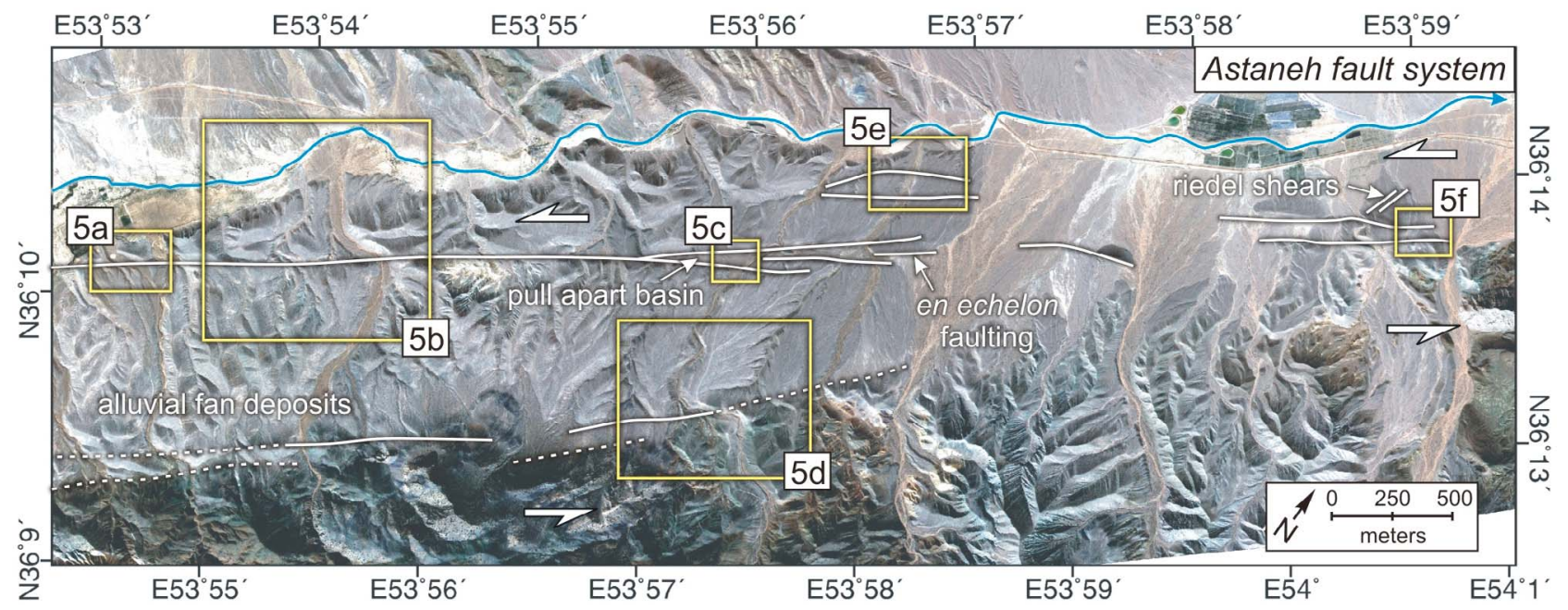

Figure 4. Quickbird satellite image of the eastern end of the Astaneh valley (see Figure 2 for location). Faulting steps north from the edge of the mountains into the valley (white lines), displacing a series of alluvial fans. The main Astaneh river drains the basin to the NE (shown by blue line). The discontinuous and complicated pattern of overlapping faults which make up the Astaneh fault system at this location have produced many features typical of strike-slip faults, such as a left-lateral pull-apart basin and en echelon faulting. Yellow boxes show locations in Figure 5, where features in the geomorphology indicate recent leftlateral movement (see text for discussion).

location of these offsets all lie in the NE corner of the Astaneh pull-apart basin, where a component of normal motion would be expected, and which, over geological time, has led to the formation of the Astaneh Valley.

\subsubsection{Between the Astaneh Valley and Kuh-e-Katkast}

[17] East of $54^{\circ} \mathrm{E}$, the fault segments which bound the north and south margins of the Astaneh valley converge, and continue east as a narrow zone of parallel faults segments (Figures 2 and 6a). Where fault segments cut across the bedrock geology (particularly through limestone), they form polished fault surfaces (Figure 6b). Slip vectors measured from the striations shown in Figure $6 \mathrm{~b}$ are consistent with left-lateral strike-slip motion subparallel to the overall strike of the Astaneh fault zone $\left(\sim 045^{\circ}\right)$.

[18] Evidence for late Quaternary left-lateral motion on this section of the Astaneh fault is visible at three sites: $4 \mathrm{~km}$ west, and $8 \mathrm{~km}$ and $15 \mathrm{~km}$ NE of Astaneh village (see Figure 6a for locations). Figure $6 \mathrm{c}$ shows the site $15 \mathrm{~km} \mathrm{NE}$ of Astaneh village, where the most active segment of the Astaneh fault system cuts across Quaternary alluvial plain deposits just north of the mountains, and displaces a stream by $20 \pm 5 \mathrm{~m}$ in a left-lateral sense (site 8 in Table 2). Figure 7a shows a site $8 \mathrm{~km} \mathrm{NE}$ of Astaneh village (site 9a in Table 2), where the Astaneh fault has displaced alluvial fans deposits by $575 \pm 35 \mathrm{~m}$ in a left-lateral sense (highlighted by the red lines). At this location, several splays strike out from the main Astaneh fault into the alluvial plain. Figure $7 \mathrm{~b}$ shows a stream which has been offset in a left-lateral sense by one of these splays (site 9b). Satellite data and topographic profiles extracted from a high-resolution DEM constructed from a kinematic GPS survey of the area (Figure 7c) indicate $18 \pm$ $3 \mathrm{~m}$ left-lateral displacement with only a minor $3.5 \mathrm{~m}$ vertical component (Figures $7 \mathrm{~d}$ and $7 \mathrm{e}$ ).

[19] West of Astaneh village, left-lateral slip appears to be concentrated along one fault segment which has displaced, with a left-lateral offset of $50 \pm 10 \mathrm{~m}$, a series of Quaternary fan deposits, highlighted by yellow pointers in Figures 8a-8d (sites $10 \mathrm{a}$ and $10 \mathrm{~b}$ ). Vertical motion across the fault is minor, and appears to vary only locally along this section of the fault. A small vertical component, "up to the south," has caused ponding of sediment along the fault at $36^{\circ} 15.542^{\prime} \mathrm{N} 54^{\circ} 2.82^{\prime} \mathrm{E}$ (Figure 8a). Such sites make excellent targets for trenching and the determination of fault slip history through paleoseismology. The blue line in Figure 8a shows the location of a trench site excavated during November 2007 (see section 5). For a discussion on fault slip rate estimates for this section of the Astaneh fault, see section 5.2.

\subsection{Astaneh Fault and the North Damghan Thrust}

[20] The Astaneh fault enters the high Alborz $\sim 10 \mathrm{~km} \mathrm{NE}$ of the Astaneh valley, where it changes strike from NE-SW to $\mathrm{E}-\mathrm{W}$ in the Kuh-e-Katkast restraining bend (see Figure 2 for location). Left-lateral motion on this section of the fault appears to be accommodated by slip on just one main fault segment, which is in contrast with the many overlapping fault segments comprising the fault system within the Astaneh Valley. Although outcrops of Quaternary deposits are sparse along this section of the Alborz, the deflection of two rivers across the fault suggest this segment has been active in the Quaternary (Figure 9a). The obliquity of this E-W segment of the Astaneh fault with the overall NE-SW left-lateral shear direction, requires a thrust component of motion to be taken up across this zone. Shortening does not appear to be accommodated on the E-W section of the Astaneh fault, as there is no obvious elevation change. This motion must instead be accommodated on the separate North Damghan thrust which strikes E-W along the edge of the range (Figure 9a and also Figure 2). In this case, the Damghan and North Damghan faults will meet at shallow depth (between $3.5 \mathrm{~km}$ and $10 \mathrm{~km}$, assuming the thrust dips 

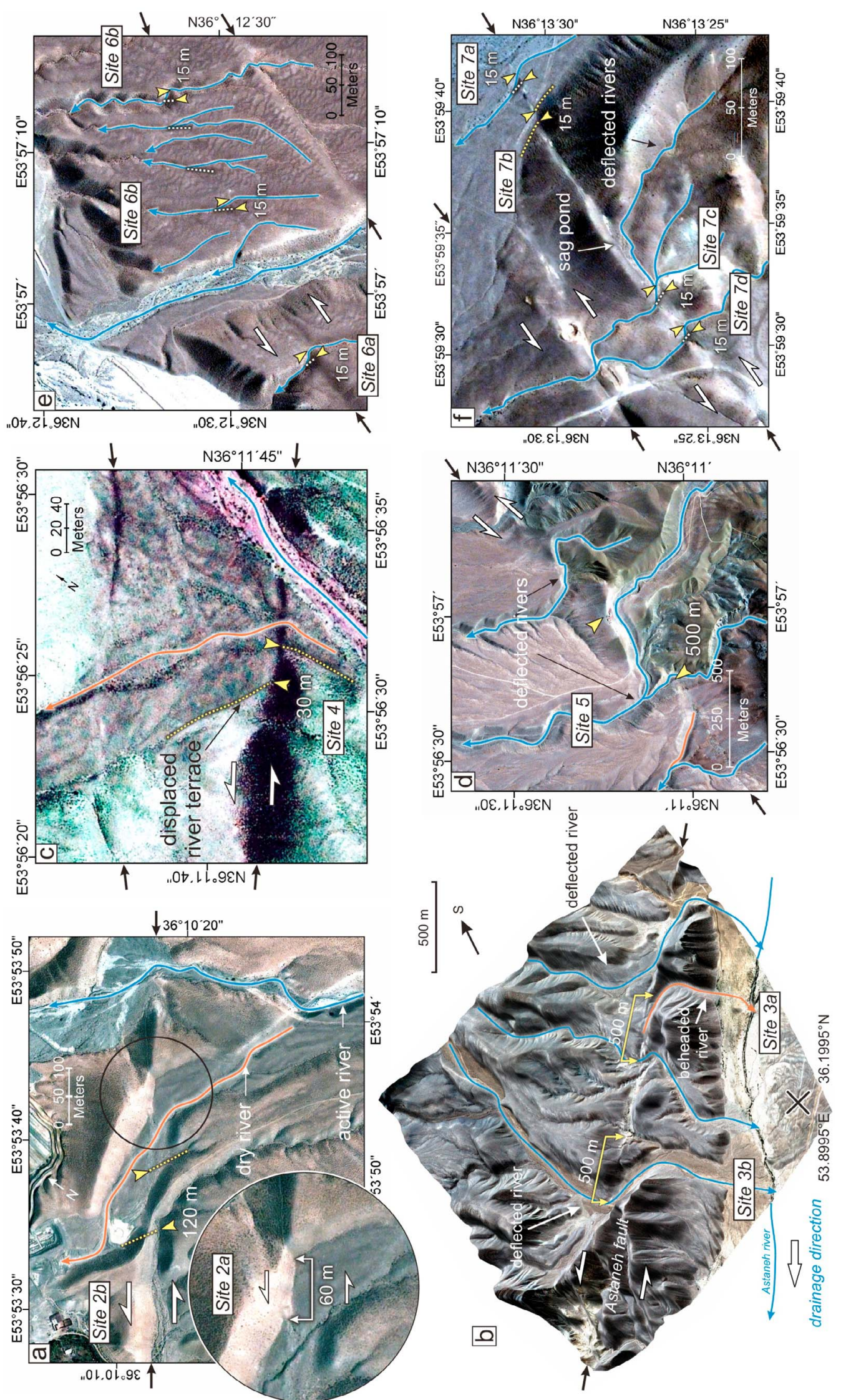

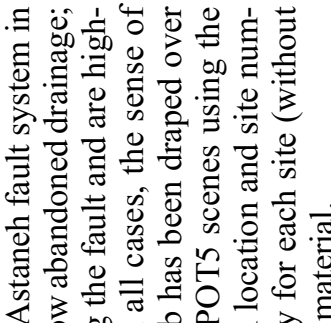

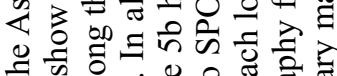

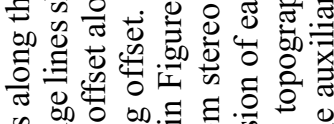

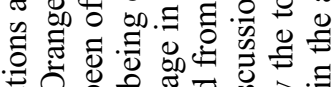

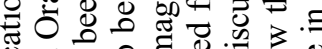

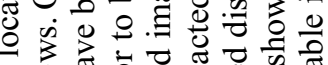

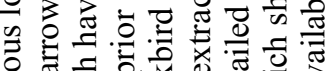

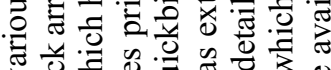

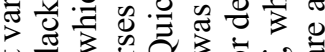

형

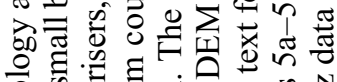

की

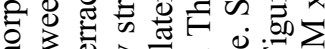

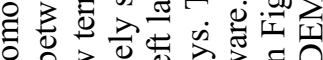

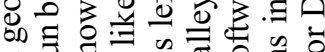

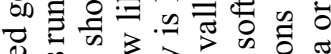

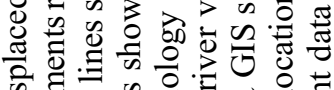

की

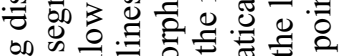

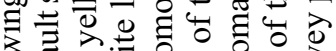
क更记

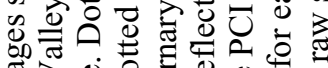

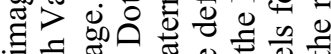

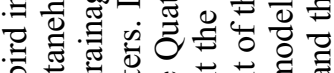

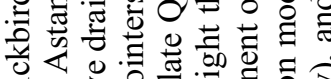

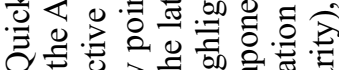

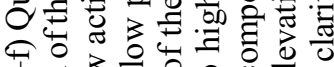

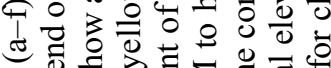

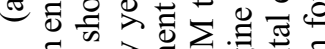

ம

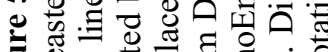

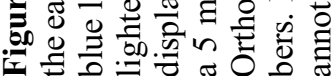



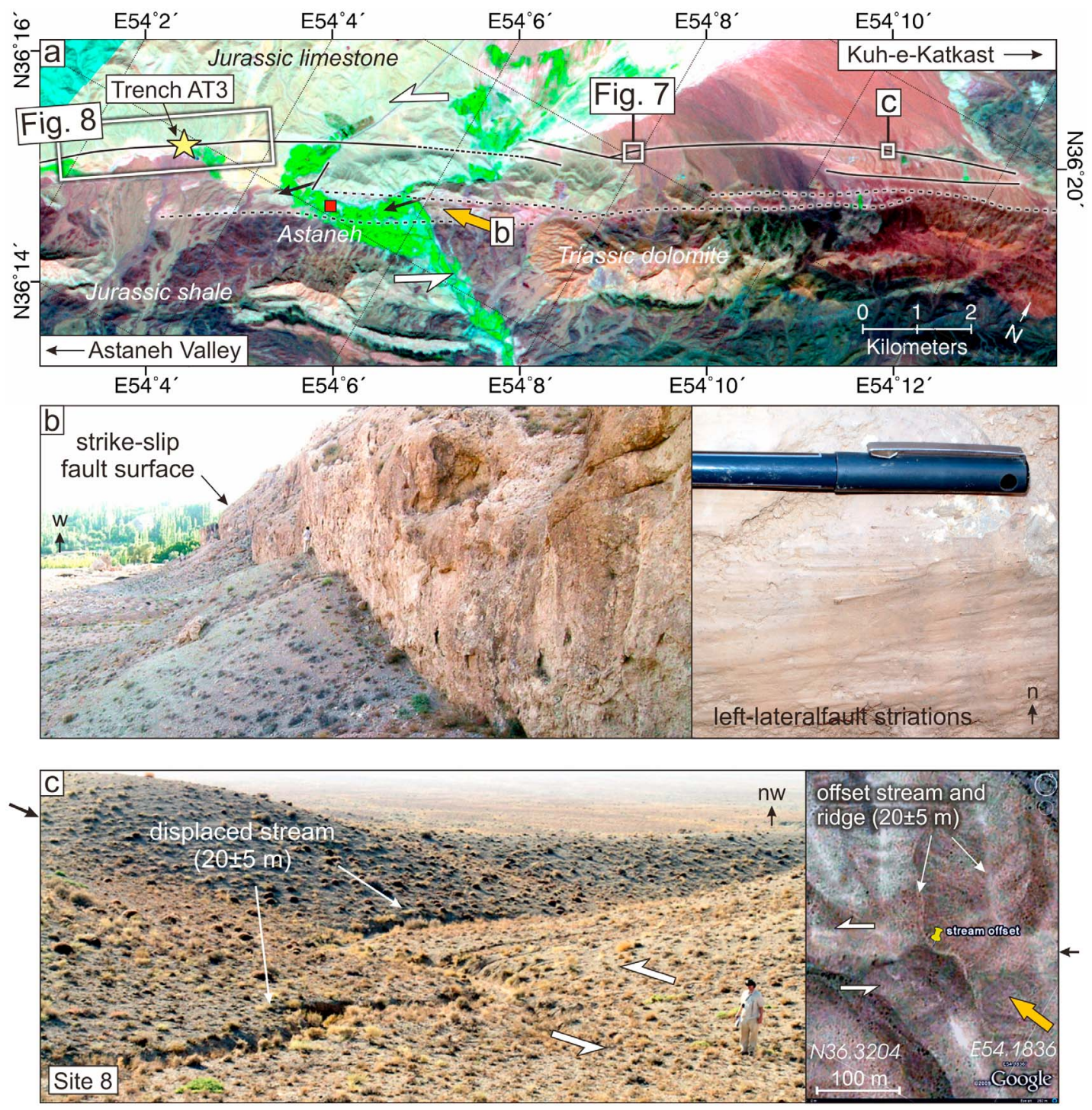

Figure 6. (a) Aster satellite image of the Astaneh fault where it leaves the NE end of the Astaneh valley and strikes NE along the edge of the topography toward the Kuh-e-Katkast restraining bend (see Figure 2 for location). Various active fault segments are shown as continuous black lines; faults which may be active but cannot be seen to displace Quaternary geomorphology are shown as dotted black lines. Contrasting geology either side of the fault zone (e.g., Jurassic limestone abuts Jurassic shale near Astaneh village) highlight the significant lateral displacement along the fault. Black arrows show slip vectors measured in the field (north relative to south), which are subparallel to the fault zone. A small normal fault lies $500 \mathrm{~m}$ north of Astaneh village, within Jurassic limestone, which runs subparallel to the road (NNE-SSW). (b) Field view, looking west from $36^{\circ} 16.57^{\prime} \mathrm{N} 54^{\circ} 06.14^{\prime} \mathrm{E}$, of a section of the Astaneh fault, which has formed a vertical polished fault surface (black arrow in Figure 6a shows orientation of slip vector, $\sim 235^{\circ}$ ). Striations lie horizontal in the fault plane, and sense of slip indicators indicate left-lateral motion. (c) Field view looking NW, taken from $36^{\circ} 19.26^{\prime} \mathrm{N} 54^{\circ} 11.12^{\prime} \mathrm{E}$, of a $20 \pm 5 \mathrm{~m}$ left-lateral stream offset. This stream (and ridge) offset is also visible in Google Earth Quickbird satellite imagery (see right inset). Google Earth imagery (CGoogle Inc. Used with permission.

between 30 and $60^{\circ}$ ) and within the seismogenic layer. Below where these faults meet at depth the geometry will become unstable, and must therefore change to a more optimum orientation and slip to accommodate the deformation. Nevertheless, partitioning of slip onto separate thrust and strike-slip faults is a common feature of Iranian tectonics at the present day [Hollingsworth et al., 2006], and is particularly important across the Alborz range [Tatar et al., 2007; Tatar and Hatzfeld, 2009].

[21] Figure $9 \mathrm{~b}$ shows a section of the North Damghan thrust fault, which runs along the foot of the range for $40 \mathrm{~km}$ and thrusts north dipping Neogene marls over Quaternary gravels of the Damghan plain. Recent uplift has caused south draining rivers to incise through their own deposits leaving river 

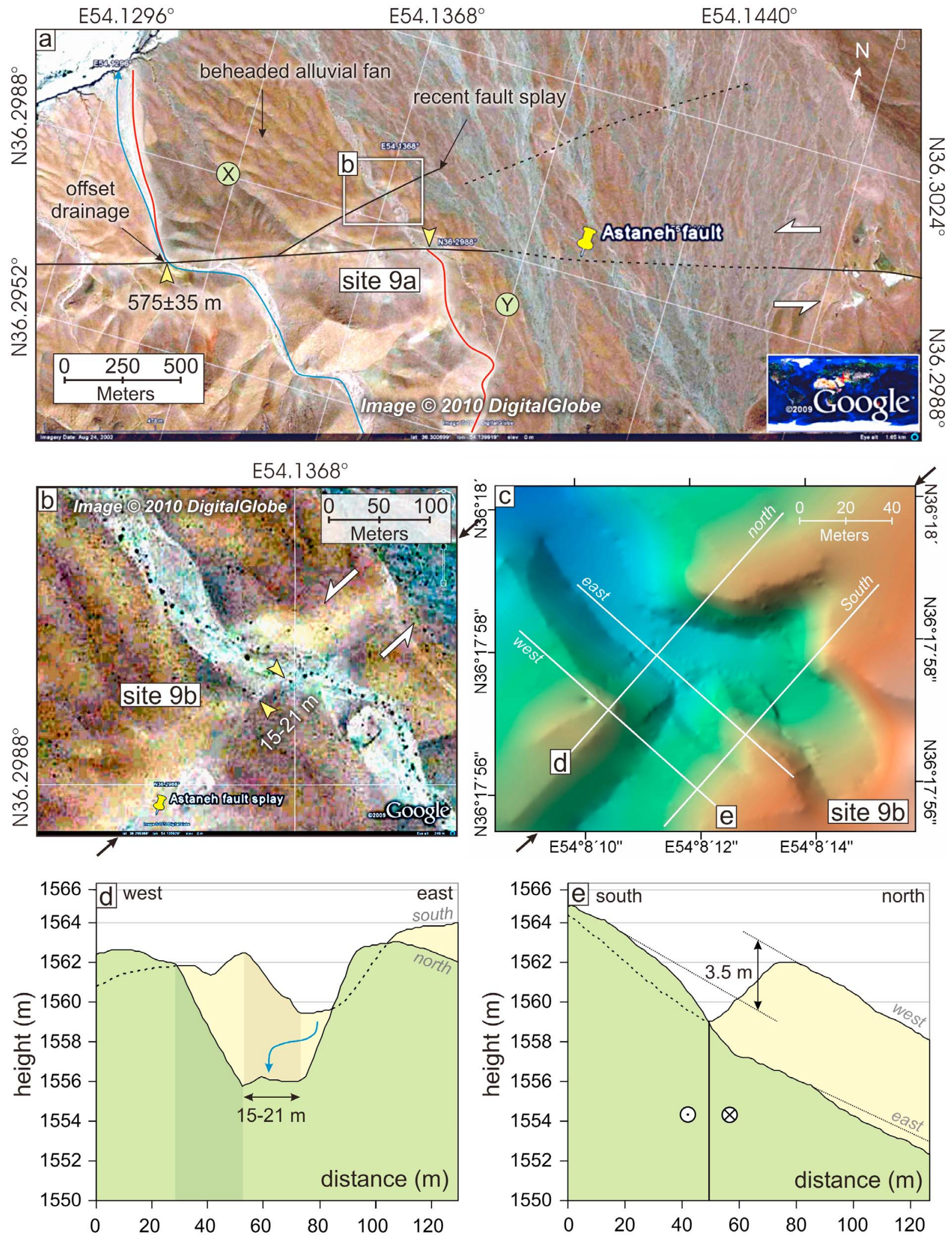

Figure 7 


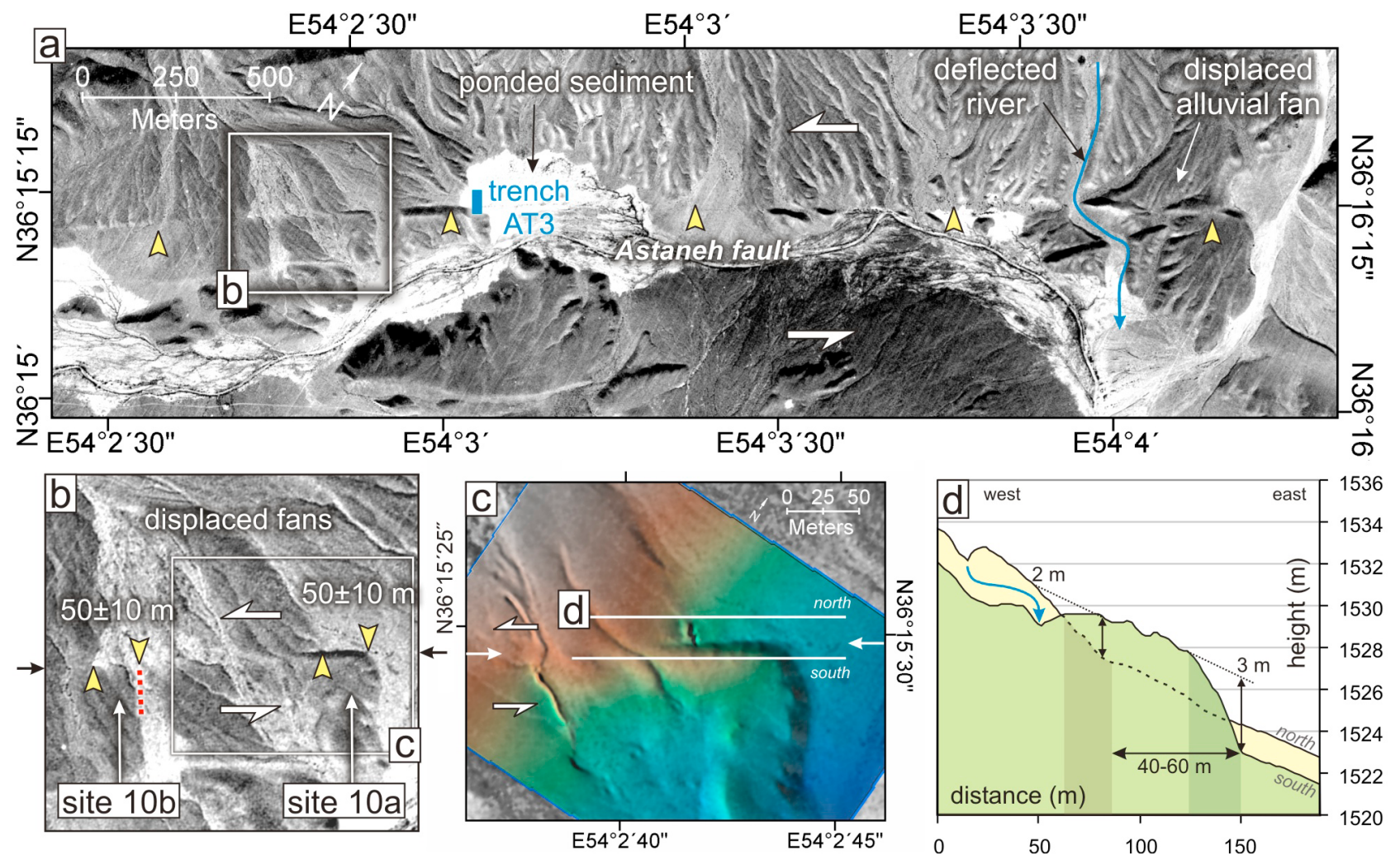

Figure 8. (a) Digitized aerial photo of the Astaneh fault (marked by yellow pointers), which displaces a series of Quaternary alluvial fans in a left-lateral sense. A deflected river is shown by a blue line. A small vertical component (up to the south) has caused sediments to be ponded along the fault scarp. The heavy blue line shows the location of trench AT3, which was excavated across the fault (see section 5 for details). (b) An alluvial fan has been displaced by $50 \pm 10 \mathrm{~m}$ in a left-lateral sense where it crosses the fault (see yellow pointers). Dotted red line shows the northward continuation of the terrace riser toward the fault. (c) Highresolution kinematic GPS DEM of the displaced fan shown in Figure 8b. (d) Topographic profiles either side of the fault are shown and indicate $50 \pm 10 \mathrm{~m}$ left-lateral displacement of this fan, with a small vertical component of $1 \mathrm{~m}$. The raw survey point data used to make this DEM is available in the auxiliary material.

terraces and abandoned alluvial fan surfaces in the hanging wall of the fault (Figure 9b). These are clearly visible in the field as low steps along the range front, where horizontal alluvial deposits lie unconformably over north dipping Neogene marls (Figure 9c).

\subsection{Damghan Fault}

[22] The third major fault in the region is the Damghan fault (see Figure 2 for location), which splays out from the south side of the Astaneh fault near 53 $53^{\prime}$ E striking NE for $40 \mathrm{~km}$, before curving to an $\mathrm{E}-\mathrm{W}$ orientation and striking eastward, parallel to the Astaneh and North Damghan faults, for another $40 \mathrm{~km}$ (Figure 2 and Figures 10a and 10b). Recent activity on the fault is indicated by a series of displaced late Quaternary alluvial fans $10 \mathrm{~km}$ north of Damghan city (Figures 10a and 10b). Digital topography indicates a small vertical component on the fault, which switches polarity along strike, and is probably the result of local variations of a steeply dipping strike-slip fault plane (Figure 10a). The sense of lateral motion on the fault is difficult to determine from the drainage, which is able to readjust quickly due to the easily erodible deposits of the alluvial plain though which the streams cut.

Figure 7. (a) Google Earth Quickbird satellite image of a beheaded Quaternary alluvial fan along a segment of the Astaneh fault. Reconstruction of fan deposits either side of the fault (labeled X and Y) indicate $\sim 600 \mathrm{~m}$ of left-lateral motion (marked by yellow arrows; red lines mark the western edge of the fan deposits). Blue line shows a left-lateral deflected river. (b) Google Earth Quickbird image of a 15-20 m left-lateral stream offset (shown by yellow pointers), on a recent splay of the Astaneh fault, which runs between the small black arrows. (c) High-resolution DEM, made using kinematic GPS data, of the stream offset in Figure 7b. White lines show the location of topographic profiles parallel and perpendicular to the fault. The raw survey point data used to make this DEM is available in the auxiliary material. (d) Profiles parallel to the fault indicate displacement of the river by $15-20 \mathrm{~m}$. (e) Profiles perpendicular to the fault show a smaller $\sim 3.5 \mathrm{~m}$ vertical component.Google Earth imagery (c) Google Inc. Used with permission. 

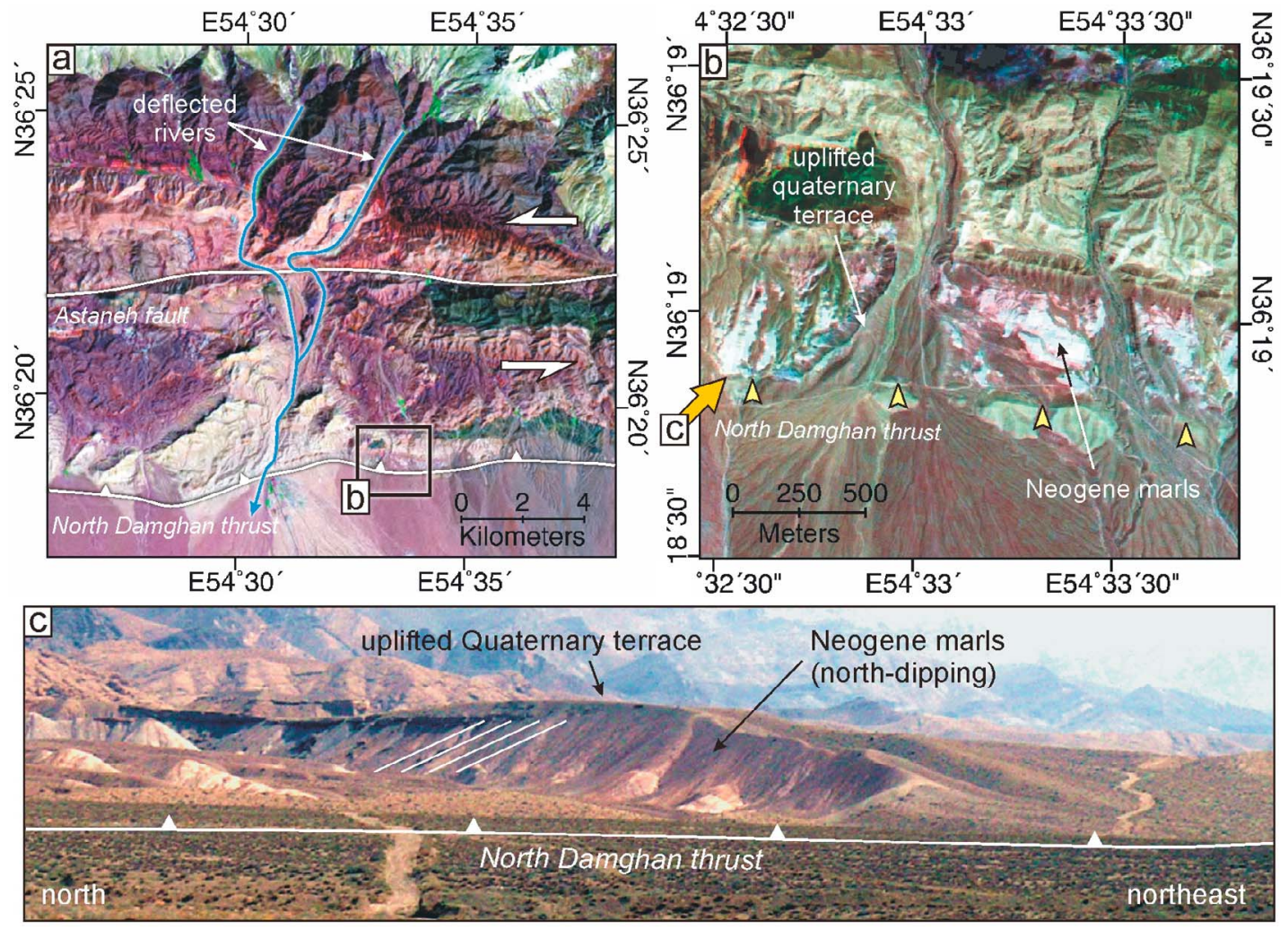

Figure 9. (a) Landsat satellite image of the Astaneh fault, where is passes through the Kuh-e-Katkast restraining bend (see Figure 2 for location). Late Quaternary movement of the fault is indicated by deflection of rivers (blue lines) where they cross thefault. The North Damghan thrust runs along the southern margin of the range. (b) Aster satellite image (pan sharpened with a georectified aerial photo), showing Quaternary terraces uplifted along the range front by the North Damghan thrust (highlighted by yellow pointers), which thrusts Neogene marls over Quaternary deposits of the Damghan plain. There is no apparent strike-slip offset on the Damghan thrust. (c) Field photo, looking east from $36^{\circ} 18.564^{\prime} \mathrm{N} 54^{\circ} 31.840^{\prime} \mathrm{E}$ at uplifted Quaternary terraces along the range front, which overlie north dipping Neogene marls.

However, a small kink in the fault directly north of Damghan coincides with a small zone of uplift (Figures 10a). This would be consistent with shortening resulting from leftlateral motion. Furthermore, because the Damghan fault appears to splay out from the Astaneh fault (Figure 2), which is clearly left-lateral, it almost certainly plays a similar role to the Astaneh fault in accommodating regional left-lateral shear. However, despite the clear expression of this fault in the Quaternary geomorphology, there is little evidence in the topography to suggest this fault has been active over longer periods of geological time. Ambraseys and Melville [1982] suggest this fault may have ruptured during the 856 A.D. earthquake. Figure 10c shows a series of en echelon (left lateral) fault scarps which are visible even in the youngest alluvial fan material and are consistent with movement on this fault during the Holocene. However, the length of this fault (and the North Damghan thrust) is significantly less than the region of maximum destruction from the 856 A.D. earthquake, which in turn coincides more closely with the $150 \mathrm{~km}$ long Astaneh fault trace (Figure 2). Based on it's geomorphological expression, the Astaneh fault is the most likely fault to have ruptured during the 856 A.D. Qumis earthquake. We test this hypothesis by investigating the paleoseismology along the section of the Astaneh fault in Figure 8a [see also Rockwell et al., 2000; Hartleb et al., 2006].

\section{Paleoseismology of the Astaneh Fault}

[23] Figure 8a shows the location of a trench (AT3) excavated along a section of the Astaneh fault system. Although the trench excavates a section of the Astaneh fault which is only visible at the surface over 5-10 km (compared with longer $20+\mathrm{km}$ sections through the Kuh-e-Katkast mountains to the NE, and a $20+\mathrm{km}$ section through the Albroz mountains to the SW, see Figure 1c), it lies within the central region of maximum destruction for the 856 A.D. earthquake (outlined in Figure 1c) [see also Ambraseys and Melville, 1982], where we might expect to find the maximum coseismic offset, and in an area where clear left-lateral displacements are visible in the recent geomorphology. Furthermore, ponding of sediments has occurred against the fault due to a small vertical component of motion, thereby providing a continuous record of sedimentation throughout the Holocene.

[24] The trench was dug in fine, silty to sandy sorted units with a few continuous clay-rich horizons. Calibrated 

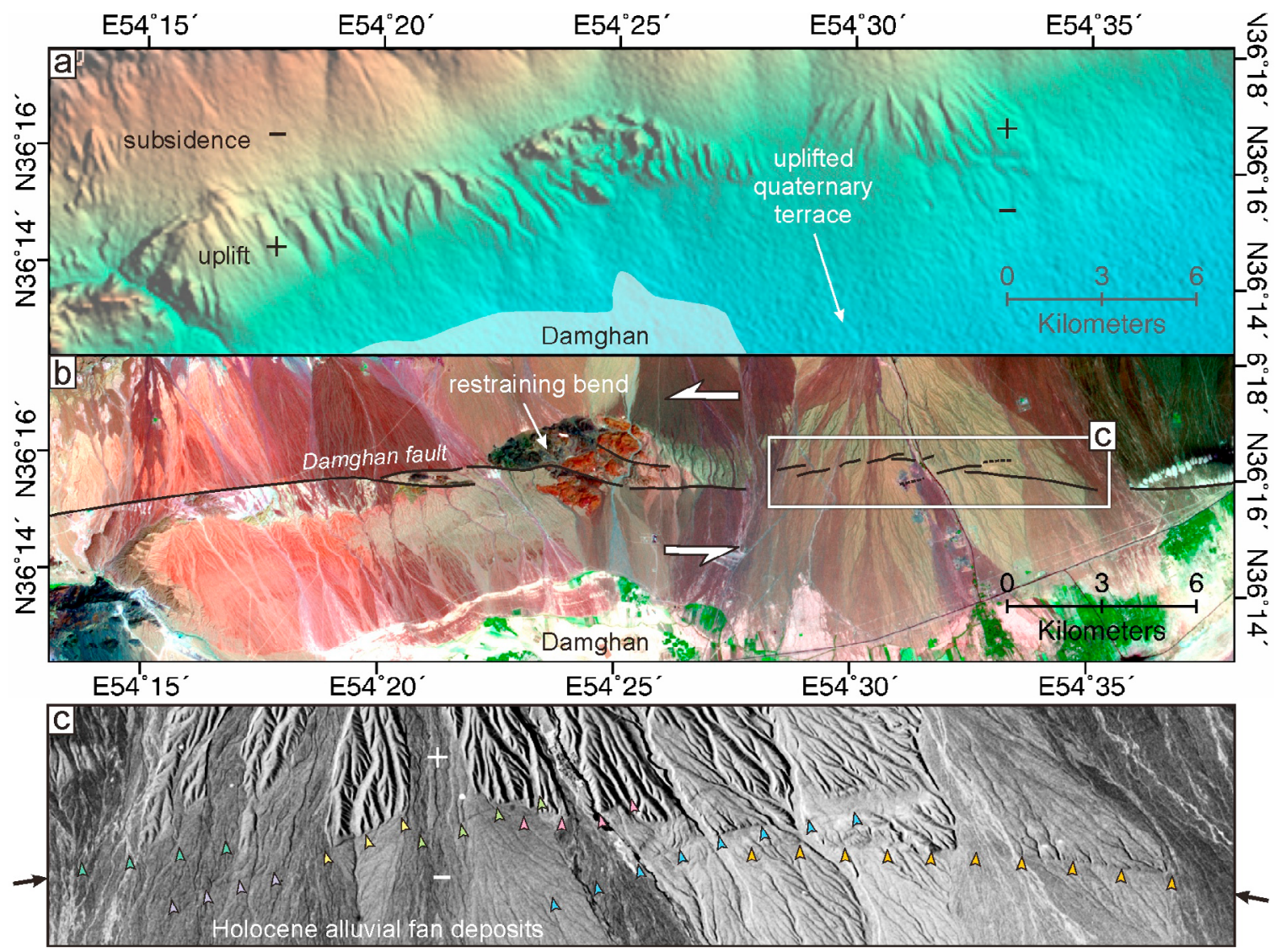

Figure 10. (a) SRTM topography of the Damghan region, which shows signs of recent vertical displacements in the alluvial plain north of the city. (b) Aster satellite image of the same region in Figure 10a. Black lines highlight the location of the Damghan fault, which cuts across Quaternary alluvial fan deposits north of the city. A small restraining bend near $54^{\circ} 25^{\prime} \mathrm{E}$ indicates a left-lateral sense of slip. When compared with Figure 10a, the polarity of uplift is seen to vary across the Damghan fault, suggesting it has a steeply dipping fault plane. (c) Corona satellite image (10 m resolution) of the Damghan fault, where it cuts across the alluvial plain. Colored pointers highlight various en echelon right-stepping fault scarps (up to the north), which indicate recent left-lateral movement on this fault.

radiocarbon ages for charcoal samples found within various units allowed the approximate timing of the last three earthquakes to be established (Figure 11). The most recent event broke the base of a stratified sandy-silty unit along rupture R3. The rupture clearly cuts the base of this unit, but not the top. Although there is no major difference in the stratigraphy, we identify an event horizon inside this sandysilty unit which separates unit 13 (faulted) from unit 14 (unfaulted). Rupture R3 is bracketed between 1306-1363 A.D. (radiocarbon age of sample AT3.C3.06 in unit 14) and 772506 B.C. (radiocarbon age of sample AT3.C2.06 at the top of unit 12). However, sample AT3.C3.06 (unit 14) is located near the tip of rupture R3. Therefore it is reasonable that rupture R3 is closer in age to 1306-1363 A.D. compared with 772-506 B.C. The timing of this event (i.e., the most recent event seen in the trench) is therefore consistent with the 856 A.D. Qumis earthquake. Seven meters NW of the main fault zone (left side of Figure 11), units 13 and 14 show a feature that could be interpreted as a fissure filled by material from unit 15 . We do not think this feature was the result of slip during a more recent earthquake, based on unpublished age constrains from a nearby trench where no event is observed during the past 700 years.

[25] We interpret the syncline formed by unit 11 , and which has been infilled by unit 12 , as evidence for a second event. Further evidence for such an event (prior to deposition of unit 12 ) is given by rupture R2, which cuts through unit 11 and terminates at the base of unit 12. Radiocarbon ages of samples AT3.C2.06 (top of unit 12) and AT3.C7.06 (unit 11) indicate this second event occurred between 772-506 B.C. and 4729 4546 B.C., respectively. A radiocarbon age from within unit 11 helps us to broadly bracket the age of this penultimate earthquake, to between 506-772 B.C. and 4546-4729 B.C. This earthquake may correspond to a known historical earthquake, identified from archaeological investigations at nearby Tappeh Hessar mound [Houtum Schindler, 1877; Ambraseys and Melville, 1982], which was occupied from the late 5th to the early 2nd millennium B.C. [Schmidt, 1937; Dyson and Lawn, 1989; Thornton and Rehren, 2009].

[26] A third event clearly ruptured unit 10 (along ruptures R1 and R3), and predates unit 11, which has infilled fissures at the top of unit 10. This event occurred between 4729 and 


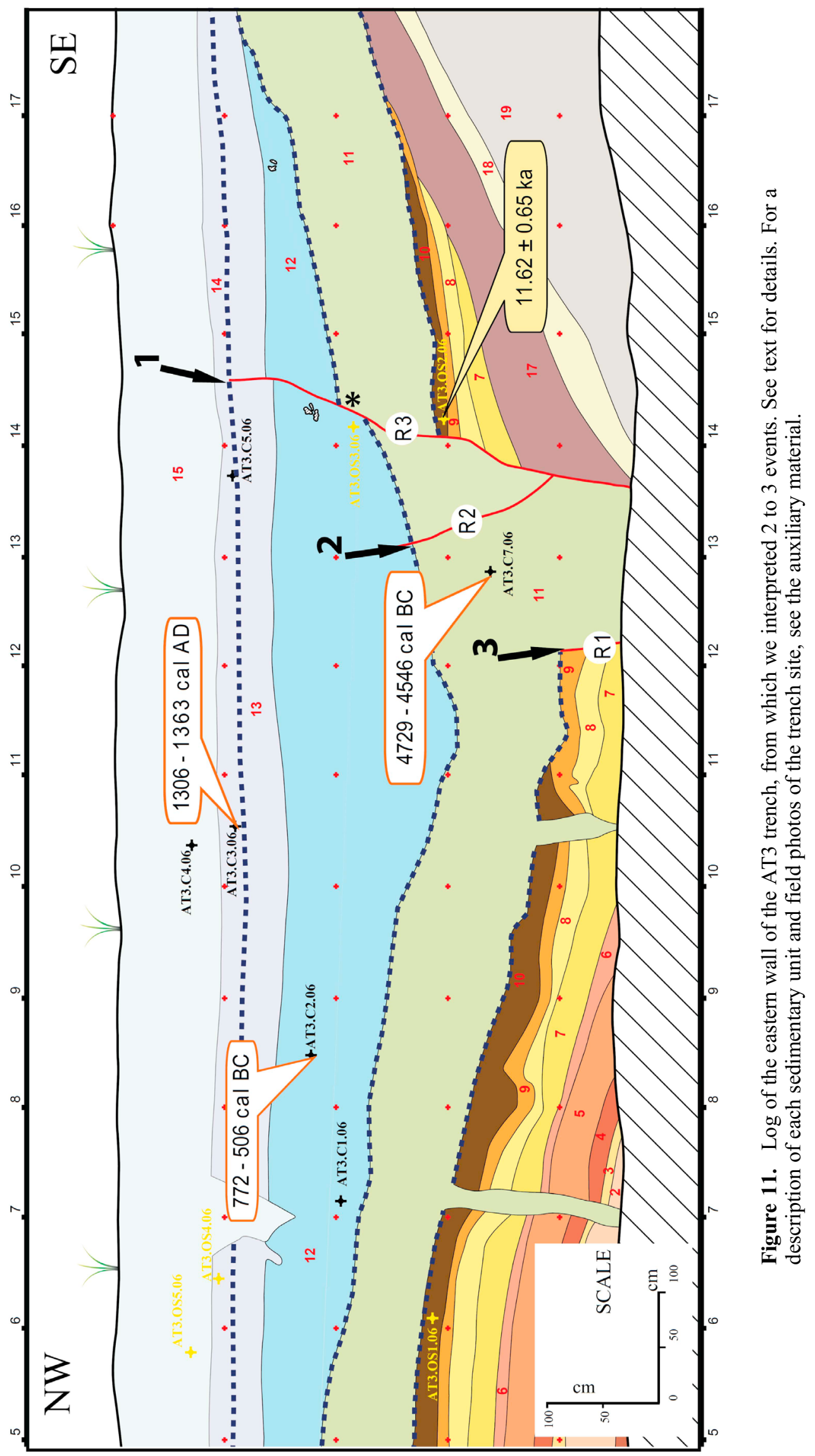



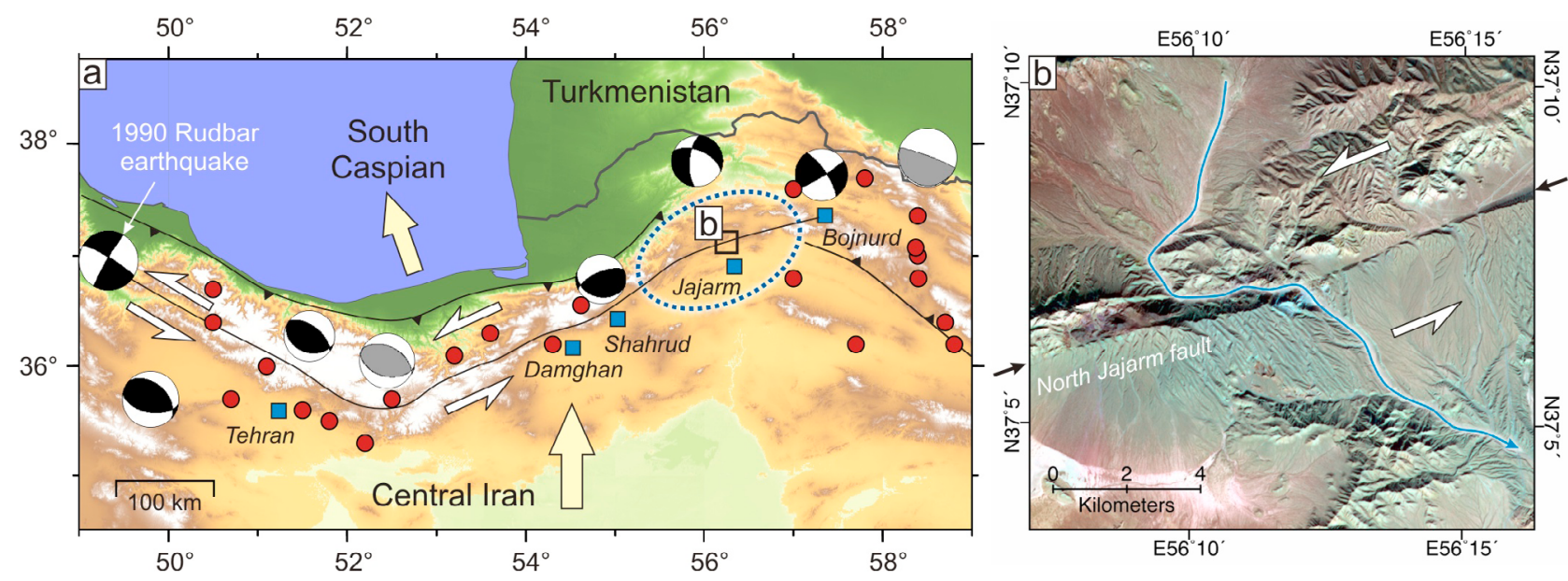

Figure 12. (a) Seismotectonic map of the Alborz mountains, north Iran. Simplified faults are shown by black lines. Regional N-S shortening is partitioned onto the Khazaar thrust, which runs along the north side of the range, and a system of overlapping and discontinuous left-lateral strike-slip fault segments, including the Shahrud fault system, Mosha and Firuzkuh faults, which strike along the south side of the range (see Figure 1c). Yellow arrows show the approximate directions of motion for the central Iran and South Caspian blocks, relative to Eurasia [see Masson et al., 2007]. Fault plane solutions are shown for earthquakes larger than $M_{w}$ 6.0; grey are first motion solutions from Jackson and Fitch [1979] and Jackson and McKenzie [1984], and black are solutions modeled from the inversion of body waveforms [Baker, 1993; Priestley et al., 1994]. Red dots show the approximate locations of large historical earthquakes $(\mathrm{M}>6.5)$ from Ambraseys and Melville [1982]. A significant gap in the seismicity occurs near the city of Jajarm and is shown by the dotted blue ellipse. (b) Landsat satellite image of the Jajarm fault, directly north of the city, where it forms a clear fault scarp cutting across Quaternary alluvial gravels. A river which drains across the fault has been deflected in a left-lateral sense by $\sim 4 \mathrm{~km}$.

4546 B.C. (deposition age of unit 11) and $11.62+/-0.65 \mathrm{ky}$ (OSL age of sample AT3.0S2.06 in unit 10). The Holocene slip history of this section of the Astaneh fault reveals 3 earthquakes between $11.62 \pm 0.65 \mathrm{ky}$ and 1306-1363 A.D. (645-702 ky) yielding a mean recurrence time of $\sim 3700$ years. This is consistent with the mean recurrence time of $3.7 \pm 4.2 \mathrm{ky}$ estimated from the average of the 2 time periods between events 1 and 2 and between events 2 and 3 .

\section{Discussion}

\subsection{Pattern of Faulting}

[27] Shortening across the east Alborz at the longitude of Damghan is partitioned onto major thrust and strike-slip fault systems bounding either side of the range (Figures 1 and 12). To the north, across-strike shortening occurs on the Khazaar thrust fault, or parallel thrust systems which have produced several large NNW directed thrust earthquakes [Hollingsworth et al., 2008], while to the south, left-lateral shear occurs on the Astaneh section of the Shahrud fault system. Further shortening is also likely to be accommodated along the southern margin of the Alborz range [Berberian et al., 1996; Vernant et al., 2004a; Tatar et al., 2007; Landgraf et al., 2009], although these thrust faults appear less pronounced in the geomorphology, and possibly interact at depth with the strike-slip faults of the Shahrud fault system [Tatar et al., 2007]. The Astaneh fault system runs NE-SW across the southern margin of the east Alborz for over $150 \mathrm{~km}$. A relatively complicated pattern of restraining and releasing bends has resulted in the formation of a large left-lateral pullapart in the Astaneh Valley, and a zone of compression in the
Kuh-e-Katkast section of the east Alborz. Late Quaternary activity on the Astaneh fault is clearly expressed in the tectonic geomorphology, and the paleoseismology results from a trench located $4 \mathrm{~km}$ west of Astaneh village are consistent with the fault rupturing in the 856 A.D. Qumis earthquake. Nevertheless, the results from a single trench are unable to resolve either the extent of the 856 A.D. rupture, the magnitude of slip, or how the slip varied along the fault. Therefore, we cannot currently answer questions regarding the spatial and temporal recurrence of slip on the Astaneh fault.

[28] The Shahrud fault system, combined with left-lateral faults in the west and central Alborz (Rudbar-Tarom, Taleghan, Mosha and Firuzkuh faults) [see also Jackson et al., 2002], forms a zone of almost continuous left-lateral shear within the Alborz between 48 and $57^{\circ} \mathrm{E}$, a distance of over $1,000 \mathrm{~km}$ (Figure 12). The fault zone extends eastward into the SW corner of the central Kopeh Dagh and, along with the right-lateral Ashkabad fault to the north, accommodates the westward extrusion, relative to central Iran and Eurasia, of the South Caspian-NW Kopeh Dagh block [Hollingsworth et al., 2008].

\subsection{Astaneh Fault Slip Rate}

[29] If the 15-20 m river offsets commonly seen along the length of the Astaneh fault have accumulated during the Holocene period (i.e., since $11 \pm 2 \mathrm{ky}$, see section 5.3 for further discussion), it would take $\sim 30$ ky to accumulate $50 \pm$ $10 \mathrm{~m}$ of displacement of the fans in Figure 8b (sites 10a and 10b), close to the location of our trench. Preliminary measurements of the age of these fans suggests a $<30 \mathrm{ky}$ abandonment age (M. Rizza, personal communication, 2010), 
which coincides with the penultimate moist period in SE Iran's climate history at 22-30 ky [Regard et al., 2005]. Therefore, the balance between sediment load and river discharge was probably perturbed by a climatic change at $30 \mathrm{ky}$, resulting in fan incision. If the 15-20 $\mathrm{m}$ stream offsets visible along the Astaneh fault have accumulated in $11 \pm 2 \mathrm{ky}$ [e.g., Regard et al., 2005; Fattahi et al., 2006, 2007; Le Dortz et al., 2009] (corresponding to a regional incision event dated at a number of sites throughout Iran), and the 50-60 m fan offsets in 22-30 ky, the slip rate for this section of the Astaneh fault would be $1.1-2.2 \mathrm{~mm} / \mathrm{yr}$ and $1.7-2.7 \mathrm{~mm} / \mathrm{yr}$, respectively (a rate of 1.7-2.2 mm/yr is consistent for both of these offsets). It should also be noted that if the last major incision event in the Astaneh valley corresponds to the slightly younger 8-9 ky event recently documented in east Iran [Le Dortz et al., 2009; Walker et al., 2010], the slip rate for the Astaneh fault determined from the 15-20 m offsets would be slightly higher, $1.7-2.5 \mathrm{~mm} / \mathrm{yr}$. These estimates are broadly consistent with GPS data, which indicates a total range-parallel left-lateral shear of $4 \pm 2 \mathrm{~mm} / \mathrm{yr}$ [Vernant et al., 2004b] and $2.5 \pm 1.5 \mathrm{~mm} / \mathrm{yr}$ [Djamour, 2004] across the central Alborz, and $3.1 \mathrm{~mm} / \mathrm{yr}$ of left-lateral shear across the east Alborz, estimated by Hollingsworth et al. [2008] using the GPS data of Masson et al. [2007]. Our estimates of the Astaneh fault slip rate are more consistent with Quaternary slip rate estimates for the left-lateral Mosha fault $(2.2 \pm 0.5 \mathrm{~mm} / \mathrm{yr})$ [Ritz et al., 2006], and the left-lateral Taleghan fault (0.6$1.6 \mathrm{~mm} / \mathrm{yr}$ ) [Nazari et al., 2009a], which form part of the same left-lateral shear system in the central and western Alborz range, respectively. The slight discrepancy between the higher range-scale left-lateral shear from GPS studies, and the lower left-lateral slip rates for the Astaneh, Mosha and Taleghan faults from Quaternary dating implies that additional, albeit minor, left-lateral shear must be accommodated on other faults throughout the range. However, both GPS data and Quaternary age determinations are not of sufficient density or precision to verify this hypothesis.

\subsection{Seismic Hazard of the Damghan Region}

[30] In section 4 we discussed the geomorphological expression of the three main active faults in the Damghan region: the Astaneh, North Damghan and Damghan faults. All three faults have clearly been active during the late Quaternary. With the recent growth of major cities in Iran, such as Semnan, Damghan, Shahrud and Gorgan (with a combined population of over half a million people), which all lie within $50 \mathrm{~km}$ of the fault, it is of paramount importance that the seismic hazard of this region be better understood to reduce the potential number of fatalities should an equally devastating earthquake occur in the future. This paper represents the first attempt to improve our understanding of the seismic hazard posed to this populous region by earthquakes.

[31] One potential analogue for the 856 A.D. Qumis earthquake is the Rudbar-Tarom earthquake $\left(M_{w} 7.3\right)$, which occurred on the southern side of the west Alborz on 21 June 1990 [Berberian et al., 1992; Tatar and Hatzfeld, 2009, Figure 12]. This event is the most destructive earthquake to have occurred in Iran over the last 50 years, killing 40,000 to 50,000 people and leaving more than half a million people homeless. The earthquake focal mechanism, obtained from body waveform modeling of broadband teleseismic data, indicated almost pure left-lateral strike-slip. Coseismic ruptures measured in the field extended more than $80 \mathrm{~km}$ along the southern west Alborz range front, occurring in discontinuous right-stepping en echelon fault segments, which showed up to $60 \mathrm{~cm}$ of left-lateral displacement along them (displacement was greater at depth) [see Berberian et al., 1992].

[32] The region of maximum destruction for the 856 A.D. Qumis earthquake extended for a length of more than $150 \mathrm{~km}$, and closely correlates with the mapped surface trace of the Astaneh fault system [Ambraseys and Melville, 1982]. If, during a single earthquake, a 100-150 km long section of the Astaneh fault system ruptured (a reasonable estimate considering the $80+\mathrm{km}$ rupture in the Rudbar-Tarom earthquake), updated earthquake scaling relations of Manighetti et al. [2007] would predict a range of coseismic displacements between $3-15 \mathrm{~m}$ (the wide range in these values reflects the variation in displacement length data for 250 large continental earthquakes occurring throughout Asia, Turkey, western United States, and Japan; see Manighetti et al. [2007] for further discussion). The structural maturity of a fault appears to be an important factor in controlling the magnitude of slip during an earthquake [Manighetti et al., 2007]; mature faults tend to break in long ruptures with low slip amplitudes $(<4-7 \mathrm{~m})$, while immature faults tend to break in shorter, more 'energetic' ruptures (slip values as high as $15 \mathrm{~m}$ ). Using the same criteria as Manighetti et al. [2007] for assessing structural maturity of faults, we qualify the Astaneh fault as immature, based on it's $150 \mathrm{~km}$ length and $2 \mathrm{~mm} / \mathrm{yr}$ slip rate (typical values for immature faults). Nevertheless, the estimated 2-10 Ma age and 30+ $\mathrm{km}$ total offset for this fault [Hollingsworth et al., 2008] are also typical of more intermediate faults. Therefore we might expect a slightly more conservative range of coseismic displacements, between 5 and $12 \mathrm{~m}$ for this fault. Furthermore, the amount of surface slip during large strike-slip earthquakes is on average $85 \%$ of that at depth [Manighetti et al., 2007]. Therefore, 5-12 m coseismic displacements may only produce surface offsets of 4-10 m. Recent stream offsets of typically 15-20 m occur throughout the Astaneh Valley (e.g., Figures 3b-3e, Figures 5e-5f, Figures 6d-6e, and Table 2), which therefore probably record slip during the last two to five earthquakes (or one to six earthquakes based on the total displacement range of 3-15 m. Older scaling relations of Scholz [1982] and Wells and Coppersmith [1994] predict a maximum coseismic displacement of 4-7 m, which requires two to six earthquakes to produce $15-20 \mathrm{~m}$ offsets). If the current drainage pattern in the Astaneh region was established at the end of the last glacial period, when other alluvial fan systems throughout E and NE Iran became incised [Regard et al., 2005; Fattahi et al., 2006, 2007] (see also section 5.2), then the 15-20 m stream offsets observed throughout the Astaneh Valley probably also date from $11 \pm 2 \mathrm{ky}$, implying two to five earthquakes have occurred on sections of the Astaneh fault system during the Holocene. These simple estimates are in good agreement with our results from trenching across the Astaneh fault (section 5), which indicates at least 3 events having occurred since $11.62 \pm 0.65 \mathrm{ky}$, with an average repeat time of $3.7 \pm 4.2 \mathrm{ky}$. Despite the broad error range associated with this estimate, it is nevertheless consistent with the average $3.6 \mathrm{ky}$ (total range: $1.8-5.9 \mathrm{ky}$ ) repeat time expected 
if the Astaneh fault slips at 1.7-2.2 mm/yr (see section 5.2), and ruptures with a characteristic coseismic displacement of 4-10 m.

[33] As the repeat time on the Astaneh fault is relatively large (around 3-4 ky) it has probably not ruptured since the 856 A.D. Qumis earthquake. It is also unlikely that any additional large earthquake in this region has been missed by historians, as this area was home to the Shahr-i Qumis (Hecatompylos), capital of the Parthian empire (247-226 A.D., see also Figure 1), and which remained a place of political importance for many centuries following this time. The Tarikhaneh mosque in Damghan (Iran's oldest mosque), which was built in the 9th century A.D. (modified from an earlier Sassanian fire temple), shows no sign of earthquake damage, implying no large earthquake has occurred since it was built. Furthermore, in the center of Damghan lies the Chehel Dokhtaran family vault dating from the Seljuk period (1037-1194 A.D.), which has also survived undamaged (a Kufi inscription on the vault indicates it was built in 1087 A.D.) (see http:/www.tarikhaneh.com/English/Index_E.htm). Therefore, over the last 2,000 years the only large earthquake in the Damghan region appears to be the 856 A.D. Qumis earthquake. Nevertheless, despite all the evidence indicating the Astaneh fault ruptured during the 856 A.D. Qumis earthquake, we cannot rule out rupture of either the Damghan or North Damghan faults during this time. Although both of these faults are significantly shorter in length than the Astaneh fault system $(\sim 40 \mathrm{~km})$, they are still capable of producing large earthquakes $\left(M_{w} 7.3\right)$, with coseismic displacements of up to $6 \mathrm{~m}$ [Wells and Coppersmith, 1994; Manighetti et al., 2007]. Furthermore, the destruction of the Damghan region in 856 A.D. may also have resulted from multiple slip events or clusters of earthquakes along the Astaneh fault over a short period of time [Hartleb et al., 2006].

[34] Although the average repeat time for the trenched section of the Astaneh fault in this study is 3-4 ky, the repeat time of large earthquakes in this area could be significantly less if the fault system ruptures in sections smaller than 100$150 \mathrm{~km}$. Also, our trench is located within the segmented bend at the eastern edge of the Astaneh pull-apart basin (Figure 2), which may possibly act as a structural barrier between rupturing fault segments (similar to the Imperial fault in southern California) [e.g., Sieh, 1996]. Therefore, the fault segment trenched in this study may experience fewer earthquakes, or earthquakes with significantly less slip, and so our record of 3 events may represent a minimum, thereby implying a shorter recurrence interval elsewhere on the fault. To resolve these issues, further trenching is required along the various fault segments which make up the Astaneh fault system (especially along the SW and NE sections where the fault trace is more continuous and less segmented, see Figure 1c) to see when they ruptured, and by how much. Important neighboring structures such as the Khazaar, Firuzkuh, Mosha, Jajarm and Meyamey faults, may also strongly influence the stress field in the east Alborz region [Stein et al., 1997; Chéry et al., 2001], thereby further controlling how and when the Astaneh fault slips. In this respect the Astaneh fault may behave very differently to plate boundary structures such as the North Anatolian fault, which appears to rupture in rare, large-magnitude events with a relatively regular recurrence interval, and which may be the typical deformation style for mature strike-slip faults in structurally isolated settings [Hartleb et al., 2006]. Furthermore, detailed trenching on the various structures throughout the east Alborz region will reveal whether slip on the Astaneh fault follows geologybased recurrence models such as uniform slip [Sieh, 1981], characteristic slip [Schwartz and Coppersmith, 1984], or fault patch slip [Sieh, 1996], which will be important for quantifying the seismic hazard posed by these faults to local populations. Nevertheless, despite the limitations of our single trench, we are able to show that the Astaneh fault is active, accommodates $\sim 2 \mathrm{~mm} / \mathrm{yr}$ of sinistral motion, and almost certainly ruptured tens of kilometers in the 856 A.D. earthquake. Therefore, cities such as Semnan, Damghan, Shahrud and Gorgan should all be considered at high risk from future earthquakes on this fault system and a major effort must be made to improve building codes for these areas. Further work toward a more comprehensive paleoseismology study of the Damghan area is ongoing, and will reveal the detailed slip history for different faults, the spatial extent of individual earthquakes, and how different faults interact with each other over several earthquake cycles. In particular, although it seems likely the various segments of the Astaneh fault within the Astaneh Valley ruptured during the 856 A.D. Qumis earthquake, we do not know if the Damghan and North Damghan faults also ruptured during this earthquake. If they did not, and if, as the historical records suggest, they haven't ruptured since this time, then they must also pose a major seismic hazard to the city of Damghan.

[35] Although the distribution of historical and teleseismically recorded earthquakes is fairly even across the whole Alborz range, a significant gap occurs in the east Alborz near the city of Jajarm (dotted blue ellipse in Figure 12a). Remote observation of the tectonic geomorphology in this region, from satellite imagery, reveals a major left-lateral strikeslip fault which cuts across Quaternary alluvial fan deposits $10 \mathrm{~km}$ north of the city (Figure 12b). Virtually nothing is known about this fault, which is clearly active and strikes NE for over $50 \mathrm{~km}$ toward the city of Bojnurd. The notable lack of historical earthquakes in this region may be biased by the relatively low population density of this harsh desert region. Nevertheless, the earthquake risk posed to the cities of Jajarm (25,000 population) and Bojnurd ( 180,000 population) by this fault must be significant. Therefore, the Jajarm fault, along with the Damghan and North Damghan faults near Damghan, should be the focus of future paleoseismology studies in this region.

\section{Conclusions}

[36] This study provides the first detailed description of active faulting in the Damghan region of the east Alborz, NE Iran (following from the initial work by Berberian et al. [1996]). Regional left-lateral shear is accommodated across the Astaneh fault, Damghan and North Damghan faults, collectively making up the SW section of the left-lateral Shahrud fault system, which cuts across the southern margin of the east Alborz mountains between Semnan and Bojnurd [Hollingsworth et al., 2008]. The Astaneh fault is clearly expressed in the late Quaternary geomorphology, and frequent stream offsets of 15-20 m appear to record the cumulative displacement of the last two to five earthquakes during the Holocene period. The results of a single-trench 
paleoseismology study along a segment of the Astaneh fault indicates this fault ruptured prior to $1306-1363$ A.D. and significantly later than 772-506 B.C., which is consistent with rupture during the 856 A.D. Qumis earthquake. Nevertheless, further trenching is critical to revealing the spatial and temporal extent of slip along the $150+\mathrm{km}$ long Astaneh fault system during both the 856 A.D. earthquake and over the late Quaternary period. These results are of more than just local interest as they provide an example of how movement on active faults may be linked to important historical earthquakes. Furthermore, the 856 A.D. Qumis earthquake is one of the five most destructive earthquakes to have occurred in recorded history. It is, therefore, perhaps surprising that so little was known about the fault which caused it. Finally, as a result of this work, the faulting in the Damghan region of the east Alborz, and their potential for generating future earthquakes are much clearer.

[37] Acknowledgments. We thank the Geological Survey of Iran for organizing all aspects of the fieldwork and for their continued support of our work in Iran. M. Fattahi (Institute of Geophysics, Tehran, and Oxford University) also provided valuable field support for a tripto Damghan. J-L Michelot and M. Massault (Orsay-Paris XI) kindly provided radiocarbon ages, which were performed in the framework of the LMC14 Artemis INSU programme. We are also grateful to Shannon Mahan (USGS Denver), who performed the OSL dating of sample AT3.OS2.06. Quickbird and Corona satellite images were purchased using funds from a NERC Postdoctoral Fellowship awarded to R.T.W. Thanks go to the staff and students of Damghan University who helped with GPS work in the Astaneh valley. J.H. would like to acknowledge support from the NCO-COMET research group during his time at Cambridge and the Gordon and Betty Moore Foundation during his time at Caltech. This work benefited from useful discussion with Manuchehr Ghorashi, Nicky White, Mahnaz Rezaeian, Keith Priestley, Barry Parsons, Conall Mac Niocaill, Bertrand Meyer, and Alex Copley. Quickbird satellite images were either purchased from DigiGlobe or obtained from Google Earth, Landsat7 images were obtained from the Global Land Cover Facility at the University of Maryland, and ASTER and SRTM data were obtained through the USGS and NASA. Stereo SPOT5 scenes used for the generation of a $5 \mathrm{~m}$ DEM of the Astaneh Valley were acquired by J.H. after a successful application to the ISIS program sponsored by CNES This manuscript was greatly improved by the comments of three anonymous reviewers. Various images in this paper were created using the public domain Generic Mapping Tools (GMT) software [Wessel and Smith, 1998]

\section{References}

Allen, M. B., M. R. Ghassemi, M. Shahrabi, and M. Qorashi (2003), Accommodation of late Cenozoic oblique shortening in the Alborz range, northern Iran, J. Struct. Geol., 25(5), 659-672, doi:10.1016/S0191-8141 (02)00064-0.

Ambraseys, N., and C. Melville (1982), A History of Persian Earthquakes, Cambridge Univ. Press, New York.

Baker, C. (1993), Active seismicity and tectonics of Iran, Ph.D. thesis, University of Cambridge, Cambridge, U. K.

Berberian, M., M. Qorashi, J. Jackson, K. Priestley, and T. Wallace (1992), The Rudbar-Tarom earthquake of 20 June 1990 in NW Persia: Preliminary field and seismological observations, and its tectonic significance, Bull. Seismol. Soc. Am., 82(4), 1726-1755.

Berberian, M., M. Ghorashi, J. Shoja-Tahheri, and M. Talebian (1996), Contribution to the seismotectonics of Iran (Part VII): Seismotectonic and earthquake-fault hazard investigations in the Semnan region, Geol. Surv. Iran, 63, 277.

Bilham, R. (2004), Earthquakes in India and the Himalaya: Tectonics, geodesy and history, Ann. Geophys., 47, 839-858.

Chéry, J., S. Carretier, and J.-F. Ritz (2001), Postseismic stress transfer explains time clustering of large earthquakes in Mongolia, Earth Planet. Sci. Lett., 194, 277-286.

Cowgill, E., R. Gold, X. Chen, J. Wang, X.-F. Arrowsmith, and J. Southon (2009), Low Quaternary slip rate reconciles geodetic and geologic rates along the Altyn Tagh fault, northwestern Tibet, Geology, 37(7), 647650, doi:10.1130/G25623A.1.

Daeron, M., L. Benedetti, P. Tapponnier, A. Sursock, and R. Finkel (2004), Constraints on the post-25-ka slip rate of the Yammouneh fault (Leba- non) using in situ cosmogenic Cl-36 dating of offset limestone-clast fans, Earth Planet. Sci. Lett., 227(1-2), 105-119, doi:10.1016/j.epsl.2004.07. 014

Djamour, Y. (2004), Contribution de la Géodésie (GPS et nivellment) à l'étude de la déformation tectonique et de l'aléa seismique sur la région de Téhéran (montagne de l'Alborz, Iran), Ph.D. thesis, Université Montpellier II, Montpellier, France.

Dolan, J., D. Bowman, and C. Sammis (2007), Long-range and long-term fault interactions in southern California, Geology, 35(9), 855-858, doi:10.1130/G23789A.1.

Dyson, R., Jr., and B. Lawn (1989), Key stratigraphic and radiocarbon elements for the 1976 Hesar sequence, in Tappeh Hesar: Reports of the Restudy Project, 1976, edited by R. Dyson Jr. and S. Howard, p. 143, Case Ed. Lett., Florence, Italy.

Engdahl, E., R. van der Hilst, and R. Buland (1998), Global teleseismic earthquake relocation with improved travel times and procedures for depth determination, Bull. Seismol. Soc. Am., 88(3), 722-743.

Engdahl, E., J. Jackson, S. Myers, E. Bergman, and K. Priestley (2006), Relocation and assessment of seismicity in the Iran region, Geophys. J. Int., 167, 761-788.

Fattahi, M., R. Walker, J. Hollingsworth, A. Bahroudi, H Nazari, M. Talebian, S. Armitage, and S. Stokes (2006), Holocene slip-rate on the Sabzevar thrust fault, NE Iran, determined using optically stimulated luminescence (OSL), Earth Planet. Sci. Lett., 245(3-4), 673-684, doi:10.1016/j.eps1.2006.03.027.

Fattahi, M., R. Walker, M. Khatib, A. Dolati, and A. Bahroudi (2007), Slip-rate estimate and past earthquakes on the Doruneh fault, eastern Iran, Geophys. J. Int., 168, 691-709.

Guest, B., G. Axen, P. Lam, and J. Hassanzadeh (2006), Late Cenozoic shortening in the west-central Alborz Mountains, northern Iran, by combined conjugate strike-slip and thin-skinned deformation, Geosphere, 2(1), 35-52, doi:10.1130/GES00019.1.

Hartleb, R., J. Dolan, O. Kozaci, H. Akyuz, and G. Seitz (2006), A 2500yr-long paleoseismologic record of large, infrequent earthquakes on the North Anatolian fault at Cukurcimen, Turkey, Geol. Soc. Am. Bull., $118(7-8), 823-840$.

Hollingsworth, J. (2007), The active tectonics of NE Iran, Ph.D. thesis, University of Cambridge, Cambridge, U. K.

Hollingsworth, J., J. Jackson, R. Walker, M. Gheitanchi, and M. Bolourchi (2006), Strike-slip faulting, rotation, and along-strike elongation in the Kopeh Dagh mountains, NE Iran, Geophys. J. Int., 166, 1161-1177.

Hollingsworth, J., J. Jackson, R. Walker, and H. Nazari (2008), Extrusion tectonics and subduction in the eastern South Caspian region since $10 \mathrm{Ma}$, Geology, 36(10), 763-766.

Hollingsworth, J., M. Fattahi, R. Walker, M. Talebian, A. Bahroudi, M. Bolourchi, J. Jackson, and A. Copley (2010), Oroclinal bending, distributed thrust and strike-slip faulting, and the accommodation of Arabia-Eurasia convergence in NE Iran since the Oligocene, Geophys. J. Int., 181, 1214-1246, doi:10.1111/j.1365-246X.2010.04591.x.

Houtum Schindler, A. (1877), Notes on some antiquities found in a mound near Damghan, J. R. Asiat. Soc., 9, 425-427.

Jackson, J. (2001), Living with earthquakes: Know your faults, J. Earthquake Eng., 5, 5-123.

Jackson, J., and T. Fitch (1979), Seismotectonic implications of relocated aftershock sequences in Iran and Turkey, Geophys. J. R. Astron. Soc., $57,209-229$.

Jackson, J., and D. McKenzie (1984), Active tectonics of the AlpineHimalayan Belt between western Turkey and Pakistan, Geophys. J. R Astron. Soc., 77(1), 185-264.

Jackson, J., K. Priestley, M. Allen, and M. Berberian (2002), Active tectonics of the South Caspian Basin, Geophys. J. Int., 148, 214-245.

Klinger, Y. (2010), Relation between continental strike-slip earthquake segmentation and thickness of the crust, J. Geophys. Res., 115 B07306, doi:10.1029/2009JB006550.

Klinger, Y., K. Sieh, E. Altunel, A. Akoglu, A. Barka, T. Dawson, T. Gonzales, A. Meltzner, and T. Rockwell (2003), Paleoseismic evidence of characteristic slip on the western segment of the North Anatolian fault, Turkey, Bull. Seismol. Soc. Am., 93, 2317-2332.

Kondo, H., V. Özaksoy, and C. Yildirim (2010), Slip history of the 1944 Bolu-Gerede earthquake rupture along the North Anatolian fault system: Implications for recurrence behavior of multisegment earthquakes, J. Geophys. Res., 115, B04316, doi:10.1029/2009JB006413.

Landgraf, A., P. Ballato, M. Strecker, A. Friedrich, S. Tabatabaei, and M. Shahpasandzadeh (2009), Fault-kinematic and geomorphic observations along the North Tehran Thrust and Mosha Fasham fault, Alborz mountains Iran: Implications for fault-system evolution and interaction in a changing tectonic regime, Geophys. J. Int., 177(2), 676-690, doi:10.1111/j.1365-246X.2009.04089.x. 
Le Dortz, K., et al. (2009), Holocene right-slip rate determined by cosmogenic and OSL dating on the Anar fault, central Iran, Geophys. J. Int., 179(2), 700-710, doi:10.1111/j.1365-246X.2009.04309.x.

Lin, A., J. Guo, K. Kano, and Y. Awata (2006), Average slip rate and recurrence interval of large-magnitude earthquakes on the western segment of the strike-slip Kunlun fault, northern Tibet, Bull. Seismol. Soc. Am., 96(5), 1597-1611, doi:10.1785/0120050051.

Manighetti, I., M. Campillo, S. Bouley, and F. Cotton (2007), Earthquake scaling, fault segmentation, and structural maturity, Earth Planet. Sci. Lett., 253(3-4), 429-438, doi:10.1016/j.eps1.2006.11.004.

Masson, F., J. Chery, D. Hatzfeld, J. Martinod, P. Vernant, F. Tavakoli, and M. Ghafory-Ashtiani (2005), Seismic versus aseismic deformation in Iran inferred from earthquakes and geodetic data, Geophys. J. Int., 160(1), 217-226, doi:10.1111/j.1365-246X.2004.02465.x.

Masson, F., M. Anvari, Y. Djamour, A. Walpersdorf, F. Tavakoli, M. Daignières, H. Nankali, and S. van Gorp (2007), Large-scale velocity field and strain tensor in Iran inferred from GPS measurements: New insight for the present-day deformation pattern within NE Iran, Geophys. J. Int., 170, 436-440, doi:10.1111/j.1365-246X.2007.03477.x.

Nazari, H., J.-F. Ritz, A. Shafei, A. Ghassemi, R. Salamati, J.-L. Michelot, and M. Massault (2009a), Morphological and paleoseismological analyses of the Taleghan fault, Alborz, Iran, Geophys. J. Int., 178, 1028-1041.

Nazari, H., M. Fattahi, B. Meyer, M. Sebrier, M. Talebian, M. Foroutan, K. Le Dortz, M. Bateman, and M. Ghorashi (2009b), First evidence for large earthquakes on the Deshir fault, central Iran Plateau, Terra Nova, 21(6), 417-426, doi:10.1111/j.1365-3121.2009.00892.x.

Nissen, E., R. Walker, A. Bayasgalan, A. Carter, M. Fattahi, E. Molor, C. Schnabel, A. West, and S. Xu (2009), The late Quaternary slip-rate of the Har-Us-Nuur fault (Mongolian Altai) from cosmogenic ${ }^{10} \mathrm{Be}$ and luminescence dating, Earth Planet. Sci. Lett., 286(3-4), 467-478.

Pantosti, D., D. Schwartz, and G. Valensise (1993), Paleoseismology along the 1980 surface rupture of the Irpinia fault: Implications for earthquake recurrence in the southern Apennines, Italy, J. Geophys. Res., 98(B4), 6561-6577.

Prentice, C., K. Kendrick, K. Berryman, A. Bayasgalan, J.-F. Ritz, and J. Spencer (2002), Prehistoric ruptures of the Gurvan Bulag fault, Gobi Altay, Mongolia, J. Geophys. Res., 107(B12), 2321, doi:10.1029/ 2001JB000803.

Priestley, K., C. Baker, and J. Jackson (1994), Implications of earthquake focal mechanism data for the active tectonics of the south caspian basin and surrounding regions, Geophys. J. Int., 118(1), 111-141, doi:10.1046 j.1365-246X.2002.01588.x.

Regard, V., et al. (2005), Cumulative right-lateral fault slip rate across the Zagros-Makran transfer zone: Role of the Minab-Zendan fault system in accommodating Arabia-Eurasia convergence in southeast Iran, Geophys. J. Int., 162(1), 177-203, doi:10.1111/j.1365-246X.2005.02558.x.

Ritz, J.-F., H. Nazari, A. Ghassemi, R. Salamati, A. Shafei, S. Solaymani, and P. Vernant (2006), Active transtension inside central Alborz: A new insight into northern Iran-southern Caspian geodynamics, Geology, 34(6), 477-480, doi:10.1130/G22319.1.

Rockwell, T., S. Lindvall, M. Herzberg, D. Murbach, T. Dawson, and G. Berger (2000), Paleoseismology of the Johnson Valley, Kickapoo, and Homestead Valley faults: Clustering of earthquakes in the eastern California shear zone, Bull. Seismol. Soc. Am., 90(5), 1200-1236.

Schmidt, E. (1937), Excavations at Tepe Hissar: Damghan, Univ. of Penn. Press, Philadelphia.

Scholz, C. (1982), Scaling laws for large earthquakes; consequences for physical models, Bull. Seismol. Soc. Am., 72(1), 1-14.

Schwartz, D., and K. Coppersmith (1984), Fault behavior and characteristic earthquakes: Examples from the Wasatch and San Andreas fault zones, J. Geophys. Res., 89, 5681-5698, doi:10.1029/JB089iB07p05681.

Sieh, K. (1981), A review of geological evidence for recurrence times of large earthquakes, in Earthquake Prediction: An International Review, Maurice Ewing Ser., edited by D. W. Simpson and P. G. Richards, vol. 4, pp. 181-207, AGU, Washington, D. C.
Sieh, K. (1996), The repetition of large-earthquake ruptures, Proc. Natl. Acad. Sci. U. S. A., 93, 3764-3771, doi:10.1073/pnas.93.9.3764.

Sieh, K., M. Stuiver, and D. Brillinger (1989), A more precise chronology of earthquakes produced by the San Andreas fault in southern California, J. Geophys. Res., 94(B1), 603-623.

Stein, R., A. Barka, and J. Dietrich (1997), Progressive failure on the North Anatolian fault since 1939 by earthquake stress triggering, Geophys. J. Int., 128, 594-604, doi:10.1111/j.1365-246X.1997.tb05321.x.

Sutherland, R., and R. Norris (1995), Late Quaternary displacement rate, paleoseismicity, and geomorphic evolution of the Alpine fault: Evidence from Hokuri Creek, South Westland, New Zealand, N. Z. J. Geol. Geophys., 38, 419-430.

Tatar, M., and D. Hatzfeld (2009), Microseismic evidence of slip partitioning for the Rudbar-Tarom earthquake (Ms 7.7) of 1990 June 20 in NW Iran, Geophys. J. Int., 176, 529-541, doi:10.1111/j.1365-246X.2008. 03976.x.

Tatar, M., J. Jackson, D. Hatzfeld, and E. Bergman (2007), The 2004 May 28 Baladeh earthquake (Mw 6.2) in the Alborz, Iran: Overthrusting the South Caspian Basin margin, partitioning of oblique convergence and the seismic hazard of Tehran, Geophys. J. Int., 170, 249-261, doi:10.1111/j.1365-246X.2007.03386.x.

Thornton, C., and T. Rehren (2009), A truly refractory crucible from fourth millennium Tepe Hissar, nrtheast Iran, J. Archaeol. Sci., 36, 2700-2712. Vernant, P., et al. (2004a), Present-day crustal deformation and plate kinematics in the Middle East constrained by GPS measurements in Iran and northern Oman, Geophys. J. Int., 157(1), 381-398, doi:10.1111/j.1365246X.2004.02222.x.

Vernant, P., et al. (2004b), Deciphering oblique shortening of central Alborz in Iran using geodetic data, Earth Planet. Sci. Lett., 223, 177 185, doi:10.1016/j.epsl.2004.04.017.

Walker, R., M. Talebian, R. Sloan, A. Rasheedi, M. Fattahi, and C. Bryant (2010), Holocene slip-rate on the Gowk strike-slip fault and implications for the distribution of tectonic strain in eastern Iran, Geophys. J. Int., 181(1), 221-228, doi:10.1111/j.1365-246X.2010.04538.x.

Washburn, Z., J. Arrowsmith, G. Dupont-Nivet, W. Feng, Z. Qiao, and C. Zhengle (2003), Paleoseismology of the Xorxol segment of the central Altyn Tagh fault, Xinjiang, China, Ann. Geophys., 5, 1015-1034.

Wellman, H. W. (1966), Active wrench faults of Iran, Afghanistan, and Pakistan, Geol. Rundsch., 55, 716-735.

Wells, A., M. Yetton, R. Duncan, and G. Stewart (1999), Prehistoric dates of the most recent Alpine fault earthquakes, New Zealand, Geology, 27, 995-998.

Wells, D., and K. Coppersmith (1994), New empirical relationships among magnitude, rupture length, rupture width, rupture area, and surface displacement, Bull. Seismol. Soc. Am., 84(4), 974-1002.

Wessel, P., and W. H. F. Smith (1998), New, improved version of Generic Mapping Tools released, Eos Trans. $A G U, 79(47), 579$

A. Bahroudi, Exploration Department, University of Tehran, PO Box 11365-4563, Tehran, Iran.

J. Hollingsworth, Division of GPS, California Institute of Technology, MC 100-23, Pasadena, CA 91125, USA. (james@gps.caltech.edu)

J. Jackson, COMET-NCEO, Department of Earth Sciences, University of Cambridge, Bullard Laboratories, Madingley Rd., Cambridge CB3 0EZ, UK.

H. Nazari, R. Salamati, and M. Talebian, Research Institute for Earth Sciences, Geological Survey of Iran, Azadi Sq., Meraj Ave., PO Box 13185-1494, Tehran, Iran.

J.-F. Ritz and M. Rizza, Géosciences Montpellier, UMR 5243-CC 60, Université Montpellier 2, Place E. Bataillon, F-34095 Montpellier CEDEX 5, France.

R. T. Walker, COMET-NCEO, Department of Earth Sciences, University of Oxford, Parks Rd., Oxford OX1 3PR, UK. 